Review

\title{
Candida glabrata Antifungal Resistance and Virulence Factors, a Perfect Pathogenic Combination
}

\author{
María Guadalupe Frías-De-León ${ }^{1,+} \mathbb{D}$, Rigoberto Hernández-Castro ${ }^{2,+}$, Esther Conde-Cuevas ${ }^{3}$, \\ Itzel H. García-Coronel ${ }^{3}$ (D) , Víctor Alfonso Vázquez-Aceituno ${ }^{2}$ (D) Marvin A. Soriano-Ursúa ${ }^{4}$ (D), \\ Eunice D. Farfán-García ${ }^{4}$, Esther Ocharán-Hernández ${ }^{4}$, Carmen Rodríguez-Cerdeira ${ }^{5,6,7}$ (D), Roberto Arenas ${ }^{5,8}$, \\ Maura Robledo-Cayetano ${ }^{1}$, Tito Ramírez-Lozada ${ }^{9}$, Patricia Meza-Meneses ${ }^{3,10}$ (D), Rodolfo Pinto-Almazán 1,4,*iD \\ and Erick Martínez-Herrera $1,4,5, *$ (D)
}

check for

updates

Citation: Frías-De-León, M.G.; Hernández-Castro, R.; Conde-Cuevas, E.; García-Coronel, I.H.; VázquezAceituno, V.A.; Soriano-Ursúa, M.A.; Farfán-García, E.D.; OcharánHernández, E.; Rodríguez-Cerdeira, C.; Arenas, R.; et al. Candida glabrata Antifungal Resistance and Virulence Factors, a Perfect Pathogenic Combination. Pharmaceutics 2021, 13, 1529. https://doi.org/10.3390/ pharmaceutics 13101529

Academic Editors: Renata Fonseca

Vianna Lopez and

Maria Nowakowska

Received: 29 July 2021

Accepted: 14 September 2021

Published: 22 September 2021

Publisher's Note: MDPI stays neutral with regard to jurisdictional claims in published maps and institutional affiliations.

Copyright: (c) 2021 by the authors. Licensee MDPI, Basel, Switzerland. This article is an open access article distributed under the terms and conditions of the Creative Commons Attribution (CC BY) license (https:// creativecommons.org/licenses/by/ $4.0 /)$.
1 Unidad de Investigación, Hospital Regional de Alta Especialidad de Ixtapaluca, Ixtapaluca 56530, Mexico; magpefrias@gmail.com (M.G.F.-D.-L.); mrobledoc@hotmail.com (M.R.-C.)

2 Departamento de Ecología de Agentes Patógenos, Hospital General "Dr. Manuel Gea González", Ciudad de México 14080, Mexico; rigo37@gmail.com (R.H.-C.); leonovictor84@gmail.com (V.A.V.-A.)

3 Maestría en Ciencias de la Salud, Escuela Superior de Medicina, Instituto Politécnico Nacional, Plan de San Luis y Díaz Mirón, Ciudad de México 11340, Mexico; condeesther999@gmail.com (E.C.-C.); itzelhaydeg@gmail.com (I.H.G.-C.); patricia_meza@ymail.com (P.M.-M.)

4 Sección de Estudios de Posgrado e Investigación, Escuela Superior de Medicina, Instituto Politécnico Nacional, Plan de San Luis y Díaz Mirón, Ciudad de México 11340, Mexico; msoriano@ipn.mx (M.A.S.-U.); efarfang@ipn.mx (E.D.F.-G.); estherocharan@hotmail.com (E.O.-H.)

5 Efficiency, Quality, and Costs in Health Services Research Group (EFISALUD), Galicia Sur Health Research Institute (IIS Galicia Sur), SERGAS-UVIGO, 36213 Vigo, Spain; carmencerdeira33@gmail.com (C.R.-C.); rarenas98@gmail.com (R.A.)

6 Dermatology Department, Hospital Vithas Ntra. Sra. de Fátima and University of Vigo, 36206 Vigo, Spain

7 Campus Universitario, University of Vigo, 36310 Vigo, Spain

8 Sección de Micología, Hospital General “Dr. Manuel Gea González”, Tlalpan, Ciudad de México 14080, Mexico

9 Servicio de Ginecología y Obstetricia, Hospital Regional de Alta Especialidad de Ixtapaluca, Ixtapaluca 56530, Mexico; titolozada@yahoo.com.mx

10 Servicio de Infectología, Hospital Regional de Alta Especialidad de Ixtapaluca, Ixtapaluca 56530, Mexico

* Correspondence: rodolfopintoalmazan@gmail.com (R.P.-A.); erickmartinez_69@hotmail.com (E.M.-H.); Tel.: +52-555-972-9800 (R.P.-A. or E.M.-H.)

+ These authors contributed equally so they must be considered co-first authors.

Abstract: In recent years, a progressive increase in the incidence of invasive fungal infections (IFIs) caused by Candida glabrata has been observed. The objective of this literature review was to study the epidemiology, drug resistance, and virulence factors associated with the C. glabrata complex. For this purpose, a systematic review (January 2001-February 2021) was conducted on the PubMed, Scielo, and Cochrane search engines with the following terms: "C. glabrata complex (C. glabrata sensu stricto, C. nivariensis, C. bracarensis)" associated with "pathogenicity" or "epidemiology" or "antibiotics resistance" or "virulence factors" with language restrictions of English and Spanish. One hundred and ninety-nine articles were found during the search. Various mechanisms of drug resistance to azoles, polyenes, and echinocandins were found for the C. glabrata complex, depending on the geographical region. Among the mechanisms found are the overexpression of drug transporters, gene mutations that alter thermotolerance, the generation of hypervirulence due to increased adhesion factors, and modifications in vital enzymes that produce cell wall proteins that prevent the activity of drugs designed for its inhibition. In addition, it was observed that the C. glabrata complex has virulence factors such as the production of proteases, phospholipases, and hemolysins, and the formation of biofilms that allows the complex to evade the host immune response and generate fungal resistance. Because of this, the C. glabrata complex possesses a perfect pathogenetic combination for the invasion of the immunocompromised host.

Keywords: Candida glabrata; antifungal resistance; variations in drug resistance; virulence factors; adherence mechanisms; enzymatic activity; formation of biofilms 


\section{Introduction}

Since the late 20th century, a progressive increase in the incidence of invasive fungal infections (IFIs) has been observed, with those caused by species of the genus Candida being more frequent (43-75\%) [1]. Candida albicans is the most frequent causative agent of IFIs [2-26]; however, C. glabrata is increasingly being isolated in cases of invasive candidiasis $[5,6,9,11,12,18,20,23,25-36]$ and is associated with increased mortality in patients $[4,5]$. This increase in the incidence of infections by C. glabrata and other non-albicans species is indirectly attributed to the development of diverse technologies and current medical treatments, such as organ transplantation, the use of medical devices of different materials such as urinary and vascular catheters, intrauterine devices, pacemakers, prosthetic valves, as well as broad-spectrum antibiotic therapies $[2,3,28,31,32,37-45]$. C. glabrata is a nonhyphae-producing haploid yeast described in 1917 by Harry Warren Anderson as part of the intestinal biota called Cryptococcus glabratus [46,47]. However, it was not until 1995 that Kevin C. Hazen recognized C. glabrata as an emerging pathogenic yeast commonly found in patients with diabetes mellitus, solid tumors, malnutrition, in neonates, and sometimes in patients with hematologic neoplasms [48]. C. glabrata has been considered a commensal and opportunistic fungus of the digestive system, which, like C. albicans, can become lethal in immunocompromised patients [40,49,50].

The ecological niche of C. glabrata is highly specialized but can adapt to different microenvironments to proliferate efficiently within the host [41,49]. Despite its adaptation to humans, C. glabrata has been isolated from abiotic surfaces in hospital settings and from the hands of health personnel [50-53], as well as outside clinical settings (fermentation of coffee beans and feces of various bird species) [50,54].

Molecular studies have shown that $C$. glabrata is more closely related to Saccharomyces cerevisiae than C. albicans. Thus, in 2003, Krutzman (2003) classified C. glabrata within the Nakaseomyces clade as it was not initially considered a human pathogen. Between 2005 and 2006, the molecular analysis of $C$. glabrata clinical isolates revealed the existence of two species, Candida nivariensis and Candida bracarensis, which are indistinguishable from C. glabrata at the phenotypic level but genetically distinct and with great potential to cause opportunistic infections. These species composed the C. glabrata complex [55-61]. However, due to the difficulty differentiating them from C. glabrata sensu stricto, the clinical significance and actual prevalence of $C$. nivariensis and $C$. bracarensis have been underestimated. The latter affects their treatment, as they exhibit greater resistance to azoles and echinocandins $[57,58,61-64]$. It should be noted that the increasing use of azole antifungals for the treatment of superficial and systemic infections by Candida glabrata has led to the selection and emergence of resistant isolates, as well as increased infections by other non-albicans species [57]. Besides, it is considered that $C$. glabrata sensu stricto is the most virulent species, followed by $C$. nivariensis and C. bracarensis $[62,63]$.

The different Candida species have virulence factors that contribute to their pathogenicity, especially in immunocompromised patients $[9,65]$. C. glabrata can secrete hydrolytic and proteolytic enzymes that allow its adherence to host cells and invasive medical devices $[39,66,67]$. Likewise, it is capable of forming biofilms that provide antifungal resistance and also exhibit great advantageous genomic plasticity. Therefore, it is considered as an aggressive yeast for humans $[39,66,67]$.

Information about the various virulence factors used by the $C$. glabrata complex species is scarce $[57,58,63]$. However, it is important to be acquainted with the virulence factors shown by the $C$. glabrata complex due to the progressive increase of infections caused by these fungi and their high rate of antifungal resistance $[2,24,29,51,68-71]$.

Therefore, the objective of this work is to conduct a systematic review of the virulence factors attributed to the $C$. glabrata complex, and the current state of antifungal resistance of the species that form this complex. 


\section{Materials and Methods}

During May 2021, an advanced search was conducted in the engines PubMed, Scielo, and Cochrane, for the period comprised between 2001 and 2021, with the terms: "Candida glabrata complex (C. glabrata sensu stricto, C. nivariensis, C. bracarensis)" associated with "pathogenicity" or "epidemiology" or "antibiotics resistance" or "virulence factors". The total number of articles found was 199. The review was performed based on the preferred reporting items for systematic reviews and meta-analyses (PRISMA) (Figure 1).

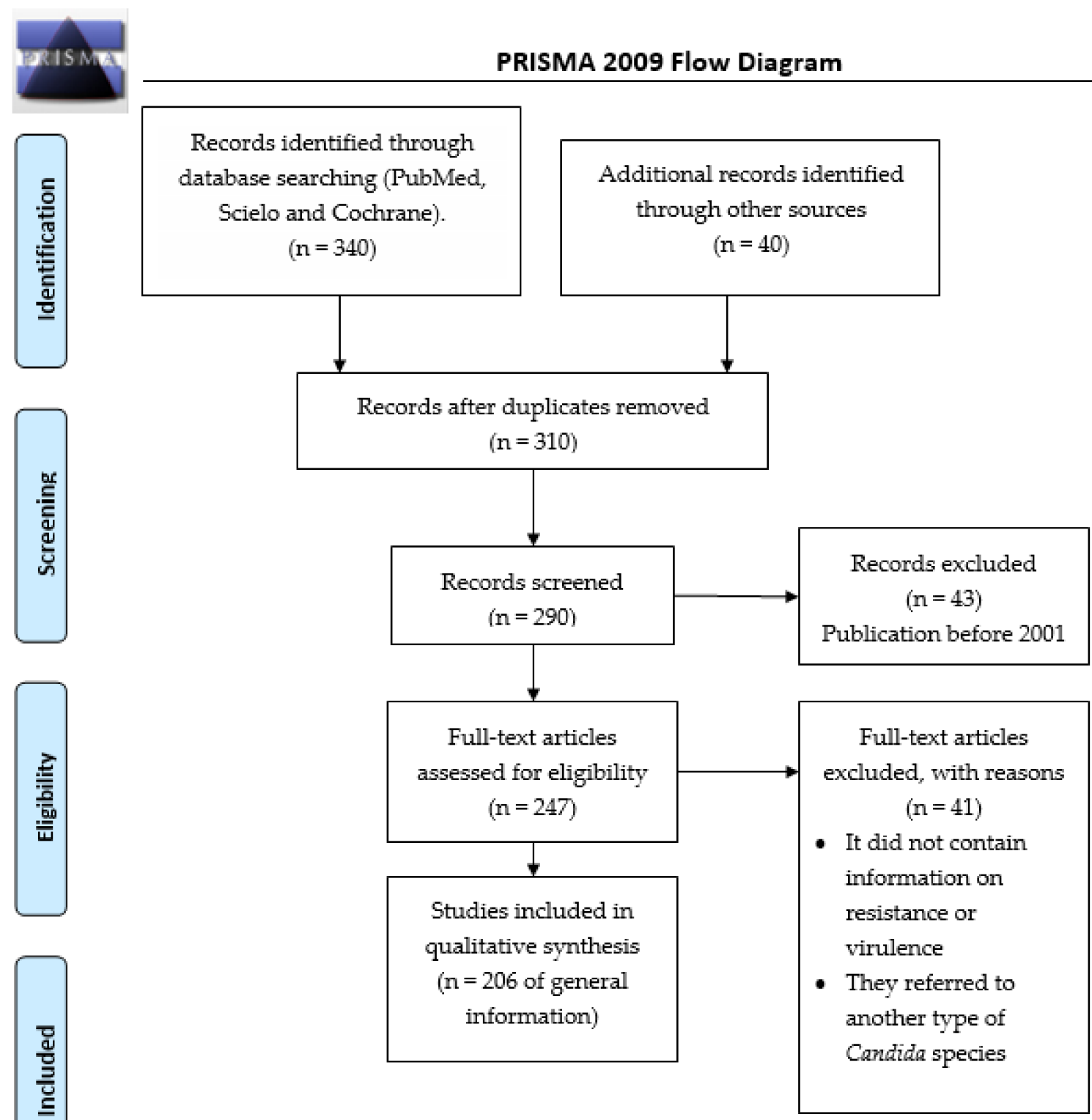

Figure 1. Flowchart of the different phases of the systematic review.

\section{Immunological Regulation of the Host}

During their evolution, Candida spp. yeasts have managed to develop strategies to grow inside human hosts, which have a wide variety of niches for growth. The various Candida species require rapid and coordinated changes in their metabolism and physiology to avoid or escape the immune surveillance and adapt to an adverse or constantly changing microenvironment $[72,73]$. Such strategies allow the fungus to survive in en- 
vironments with nutrient limitations, antimicrobial peptide production, $\mathrm{pH}$ fluctuations, oxygen deprivation, temperature changes or with oxidative, nitrosamine, and cationic stress $[72,74]$.

The fungal cell wall is responsible for mediating the initial steps of the host-fungus interaction for their mutual recognition and activation of the signal transduction through the host receptors $[73,75]$. The accessibility to the $\beta$-glucan and chitins present in the fungal cell wall is crucial for the recognition and activation of the host's immune system [73].

As a mechanism of immune evasion, the species of the genus Candida have successfully managed to mask their cell membrane's pathogen-associated molecular patterns (PAMP) secreting specific proteases aimed at the opsonization of the complement, to avoid being recognized by the multiple pattern recognition receptors (PRRs) present in the cells of the innate immune system (dendritic cells, macrophages, monocytes, and neutrophils) that are responsible for inducing phagocytosis and the production of cytokines and proinflammatory chemokines [72,73].

When the host's immune system recognizes the components of the fungal cell wall, especially the $\beta$-glucan or chitin, the phagocytosis and production of proinflammatory cytokines are triggered [73]. The phagocytes will attempt to kill pathogens by producing toxic reactive oxygen species (ROS) and reactive nitrogen species (RNS) as an antimicrobial defense mechanism $[72,73,76]$. When the ROS interact with nitric oxide (NO), they produce toxins that irreversibly damage the pathogen, thus fighting the invasion [72].

Seider et al. noted that $\beta$-glucan and chitin are vital to produce tumor necrosis factoralpha (TNF- $\alpha$ ) in C. glabrata. The unmasking of both components in the fungus causes an inflammatory response altered by monocyte-derived macrophages (MDMs) by induction of the TNF- $\alpha$. The higher the chitin content, the greater the production of TNF-alpha [73]. Likewise, the increased exposure to $\beta$-glucan and chitin was also associated with increased ROS production [73].

The genus Candida species can induce their capture through phagocytes in endothelial and epithelial cells, using them as a "safe home", preventing the maturation of the phagolysosome and its destruction [72,77]. It has been reported that $C$. glabrata can survive within the phagosome due to its ability to generate strong stress responses against ROS, neutralizing the phagocytic environment and thus escaping phagocytosis [72,77-80]. Such a phenomenon requires the activation of different genes in the pathogen $(S k n 7 p, Y a p 1 p$, Msn2p, and Msn4p) [76,81,82] that encode proteins (Transcription factors Skn7, CgYap1, MSN2p, MSN4p) involved in detoxification and repair such as catalases, superoxide dismutases, glutathione peroxidases, and thioredoxins $[76,80,81,83]$. Both in C. albicans and C. glabrata these stress pathways are mainly regulated by the stress-activated protein kinase (SAPK) Hog1 [73,84,85], the Cap1 transcription factor, and the DNA damage checkpoint kinase Rad53, which, together with the CTA4 transcription factor, play an important role in triggering the response to osmotic, oxidative, and nitrosative stress $[73,85]$. It has been observed that deleting these genes results in virulence attenuation, alters stress tolerance, and therefore decreases phagocytic survival [72]. It is also known that, according to that mentioned above, C. glabrata has important antioxidant systems, so the ROS play a minor role in destroying this pathogen [73].

Certain genes like CgVPS15 and CgVPS34 (orthologs of Vps15 and Vps34 in S. cerevisiae) have also been identified to be relevant for regulating the phosphatidylinositol 3'-kinase (PI3K) signaling pathway. It is known that in C. glabrata, the PI3K signaling is essential for the microorganism's survival inside the host's macrophages. In a mouse model of systemic infection, the deletion of CgVPS15 and CgVPS34 caused altered protein trafficking in C. glabrata and high susceptibility to stress, as well as hyperadherence to epithelial cells, which led to the yeast not being able to survive inside the macrophages. The study concluded that both genes are needed to modulate the phagolysosome acidification and survival in macrophages, and that fungal PI3K is critical for the pathogenesis and virulence of C. glabrata [86]. 
Micronutrient limitation is also an effective way to control the proliferation of pathogens $[72,77,81]$. This is especially true for micronutrients such as iron and zinc, which are important for the development of intracellular pathogens such as C. glabrata [87]. Upon such restriction, C. glabrata has managed to develop strategies to obtain micronutrients that allow proliferation, survival, and even greater resistance to phagocytosis [72,73]. C. glabrata can acquire free iron and iron from iron-binding proteins such as hemoglobin, ferritin, and transferrin. The siderophore-iron transporter Sit1 is responsible for mediating the iron acquisition, giving the microorganism the ability to survive phagocytosis and replicate within the host's macrophages due to the use of intracellular iron deposits [72]. Likewise, it can escape immunological surveillance by kidnapping zinc in vacuoles to regulate $\mathrm{Zn}$ homeostasis [72,77]. Furthermore, it has been observed that the deletion of ZRC1 (involved in the regulation of $\mathrm{Zn}$ kidnapping in S. cerevisiae) in C. glabrata results in a survival defect and is crucial for immune evasion [77].

It has also been observed that interferons such as IFN-I play a crucial role in favoring C. glabrata persistence in organs such as the brain, liver, and spleen in murine models, causing dysregulation of the cellular iron homeostasis, thus facilitating its acquisition by the pathogen [88]. IFN-I has an important role in the regulation of $\mathrm{Zn}$ homeostasis as it reduces plasmatic concentrations of this micronutrient by inducing the expression of hepatic metallothionein, which captures $\mathrm{Zn}$ for cytoplasmic transport during the intracellular mobilization of Zn. Studies show that IFN-I suppresses metallothionein gene expression after infection with C. glabrata in in vitro and in vivo models [77].

Rasheed et al. suggest in their study that CgYapsins (encoded by the CgYPS1-111 genes) inhibit IL-1 $\beta$ production in macrophages so that the microorganism can proliferate and spread. The increased IL-1 $\beta$ output is part of the host's immune system's response to infection [89]. The study conducted in a murine model observed that a mutant strain of $C$. glabrata lacking the coding genes for CgYapsins showed less virulence and died inside the macrophages. Therefore, the authors suggest that given the absence of CgYapsins, the IL-1 $\beta$ dependent inflammatory response is not inhibited inside the macrophages. Consequently, the microorganism dies as it lacks the aspartyl proteases that contribute to its survival [89].

The dependence between the IL-1 $\beta$ output and CgYapsins occurs because yapsins inhibit IL-1 $\beta$ production in macrophagues. Thus, the pathogen survives the host's defense mechanism, proliferating and subsequently spreading. Conversely, in the absence of yapsins, there is no inhibition of IL- $1 \beta$, and the pathogen dies inside the macrophages [89].

\section{Antifungal Resistance of the C. glabrata Complex}

C. glabrata is characterized by the exhibition of a high resistance rate to the different antifungal therapies currently available $[11,52,53,70,74,87,90,91]$. Low susceptibility to azoles, polyenes, and echinocandins used in the treatment of invasive or serious infections caused by the $C$. glabrata complex has been associated with a higher mortality rate $[29,90,92]$. In addition, recent reports indicate a high resistance of $C$. glabrata to medicines such as caspofungin and micafungin, which is alarming $[11,52,87]$. Because of this, the Infectious Diseases Society of America guidelines initially recommend treatment with echinocandins in patients with candidemia and risk factors for developing infections caused by microorganisms of the C. glabrata complex $[93,94]$.

\subsection{Resistance to Azoles}

As mentioned above, one of the known virulence factors of the C. glabrata complex is its intrinsic low susceptibility to azoles, especially fluconazole [7,51,53,67,95-97]. In general, this is because azoles are the first prophylactic choice against fungal infections due to their low cost, and the second choice for invasive infections produced by different Candida species, generating cross-resistance to the other azoles [96,98-100].

On the other hand, it has been observed that in different world regions, the pharmacological susceptibility to azoles presents variations as well as the proportion of cases between the types of candidiasis (Table 1) [3,64,101-104]. 
Table 1. Susceptibility variations of Candida glabrata complex per continent.

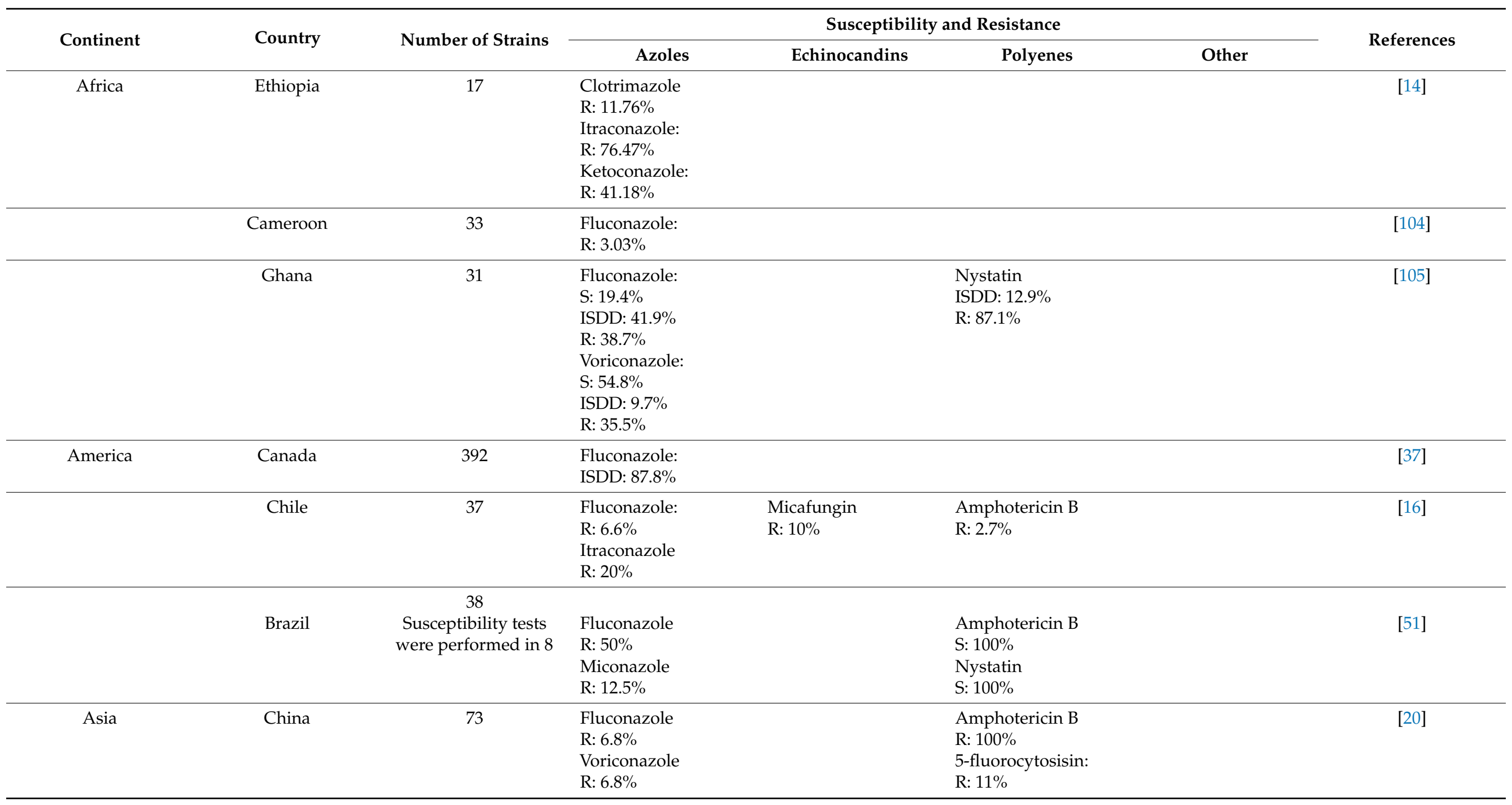


Table 1. Cont.

\begin{tabular}{|c|c|c|c|c|c|c|c|}
\hline \multirow{2}{*}{ Continent } & \multirow{2}{*}{ Country } & \multirow{2}{*}{ Number of Strains } & \multicolumn{4}{|c|}{ Susceptibility and Resistance } & \multirow{2}{*}{ References } \\
\hline & & & Azoles & Echinocandins & Polyenes & Other & \\
\hline & India & 21 & $\begin{array}{l}\text { Fluconazole } \\
\text { S: } 100 \% \\
\text { Itraconazole } \\
\text { S: } 100 \% \\
\text { Posaconazole } \\
\text { S: } 100 \% \\
\text { Ketoconazole } \\
\text { S: } 100 \% \\
\text { Voriconazole } \\
\text { S: } 100 \%\end{array}$ & $\begin{array}{l}\text { Caspofungin } \\
\text { S: } 100 \%\end{array}$ & $\begin{array}{l}\text { Amphotericin B } \\
\text { S: } 100 \% \\
\text { 5-fluorocytosisin } \\
\text { S: } 100 \%\end{array}$ & & [21] \\
\hline & India & 22 & $\begin{array}{l}\text { High Resistance to } \\
\text { clotrimazole, } \\
\text { fluconazole, } \\
\text { itraconazole, } \\
\text { ketoconazole: } 100 \%\end{array}$ & & $\begin{array}{l}\text { High Resistance to } \\
\text { nystatin: } 100 \%\end{array}$ & & {$[70]$} \\
\hline & Iran & 4 (C. nivariensis) & $\begin{array}{l}\text { Fluconazole } \\
\text { S: } 100 \% \\
\text { Itraconazole } \\
\text { S: } 100 \% \\
\text { Voriconazole } \\
\text { S: } 100 \% \\
\text { Posaconazole } \\
\text { S: } 100 \% \\
\end{array}$ & $\begin{array}{l}\text { Micafungin } \\
\text { S: } 100 \%\end{array}$ & $\begin{array}{l}\text { Amphotericin B } \\
\text { S: } 100 \% \\
\text { 5-fluorocytosine } \\
\text { S: } 100 \%\end{array}$ & & [106] \\
\hline & Nepal & 9 & $\begin{array}{l}\text { Fluconazole } \\
\text { S: } 66.6 \% \\
\text { ISDD: } 11.1 \% \\
\text { R: } 22.2 \% \\
\text { Voriconazole: } \\
\text { ISDD: } 88.8 \% \\
\text { R: } 11.1 \%\end{array}$ & $\begin{array}{l}\text { Caspofungin } \\
\text { S: } 100 \%\end{array}$ & $\begin{array}{l}\text { Amphotericin B } \\
\text { ISDD: } 100 \%\end{array}$ & & [95] \\
\hline & Kuwait & 11 & $\begin{array}{l}\text { Fluconazole: } \\
\text { R: } 64 \% \\
\text { ISDD: } 36 \%\end{array}$ & & & & [107] \\
\hline
\end{tabular}


Table 1. Cont.

\begin{tabular}{|c|c|c|c|c|c|c|c|}
\hline \multirow{2}{*}{ Continent } & \multirow{2}{*}{ Country } & \multirow{2}{*}{ Number of Strains } & \multicolumn{4}{|c|}{ Susceptibility and Resistance } & \multirow{2}{*}{ References } \\
\hline & & & Azoles & Echinocandins & Polyenes & Other & \\
\hline & Kuwait & 75 & $\begin{array}{l}\text { Fluconazole: } \\
\text { R: } 48 \% \\
\text { ISDD: } 52 \%\end{array}$ & $\begin{array}{l}\text { Micafungin: } \\
\text { R: } 4 \% \\
\text { ISDD: } 2.67 \% \\
\text { Caspofungin: } \\
\text { R: } 5.33 \%\end{array}$ & $\begin{array}{l}\text { Amphotericin B } \\
\text { R: } 6.67 \%\end{array}$ & & [108] \\
\hline & Turkey & 12 & $\begin{array}{l}\text { Fluconazole } \\
\text { R: } 100 \%\end{array}$ & & & & [109] \\
\hline & Turkey & 83 & $\begin{array}{l}\text { Fluconazole: } \\
\text { R: } 9.2 \% \\
\text { Itraconazole: } \\
\text { R: } 45.8 \% \\
\text { Voriconazole } \\
\text { R: } 43.4 \%\end{array}$ & & & & [71] \\
\hline \multirow[t]{3}{*}{ Europe } & Spain & 14 & $\begin{array}{l}\text { Fluconazole: } \\
\text { ISDD: } 100 \% \\
\text { Itraconazole: } \\
\text { R: } 50 \% \\
\text { Voriconazole: } \\
\text { S: } 100 \%\end{array}$ & $\begin{array}{l}\text { Caspofungin: } \\
\text { S: } 92.9 \% \\
\text { ISDD: 7.1\% } \\
\text { Micafungin: } \\
\text { S: } 100 \% \\
\text { Anidulafungin: } \\
\text { S: } 85.7 \% \\
\text { ISDD: } 14.3 \%\end{array}$ & $\begin{array}{l}\text { Amphotericin B } \\
\text { S: } 100 \% \\
\text { 5-fluorocytosisin: } \\
\text { S: } 100 \%\end{array}$ & & [101] \\
\hline & Ireland & 21 & $\begin{array}{l}\text { Fluconazole: } \\
\text { R: } 37 \%\end{array}$ & & $\begin{array}{l}\text { Amphotericin B: } \\
\text { R: } 14 \%\end{array}$ & & [5] \\
\hline & Poland & 445 & $\begin{array}{l}\text { Fluconazole: } \\
\text { ISDD: } 100 \% \\
\text { Itraconazole: } \\
\text { R: } 41 \% \\
\text { Posaconazole: } \\
\text { R: } 50 \% \\
\text { Voriconazole: } \\
\text { S: } 83 \%\end{array}$ & $\begin{array}{l}\text { Caspofungin, } \\
\text { anidulafungin and } \\
\text { micafungin: } \\
\text { S: } 100 \%\end{array}$ & $\begin{array}{l}\text { Amphotericin B: } \\
\text { S: } 100 \%\end{array}$ & & {$[57]$} \\
\hline
\end{tabular}


Table 1. Cont.

\begin{tabular}{|c|c|c|c|c|c|c|c|}
\hline \multirow{2}{*}{ Continent } & \multirow{2}{*}{ Country } & \multirow{2}{*}{ Number of Strains } & \multicolumn{4}{|c|}{ Susceptibility and Resistance } & \multirow{2}{*}{ References } \\
\hline & & & Azoles & Echinocandins & Polyenes & Other & \\
\hline & Greece & 34 & $\begin{array}{l}\text { Fluconazole: } \\
\text { ISDD: } 94 \% \\
\text { R: } 6 \%\end{array}$ & $\begin{array}{l}\text { Anidulafungin: } \\
\text { S: } 97 \% \\
\text { R: } 3 \% \\
\text { Caspofungin } \\
\text { S: } 88 \% \\
\text { ISDD: } 3 \% \\
\text { R: } 9 \% \\
\text { Micafungin } \\
\text { S: } 97 \% \\
\text { R: } 3 \% \\
\end{array}$ & & & [24] \\
\hline & Germany & 176 & $\begin{array}{l}\text { Fluconazole: } \\
\text { R: } 38 \%\end{array}$ & $\begin{array}{l}\text { Anidulafungin: } \\
\text { S: } 52 \% \\
\text { R: } 48 \%\end{array}$ & & $\begin{array}{l}\text { Combined resistance } \\
\text { to fluconazole and } \\
\text { echinocandins: } 14 \%\end{array}$ & [110] \\
\hline & Switzerland & 5 & $\begin{array}{l}\text { Fluconazole: } \\
\text { ISDD: } 100 \%\end{array}$ & $\begin{array}{l}\text { Caspofungin, } \\
\text { anidulafungin and } \\
\text { micafungin } \\
\text { R: } 100 \%\end{array}$ & & & [111] \\
\hline & United Kingdom & 7225 & & $\begin{array}{l}\text { Caspofungin, } \\
\text { anidulafungin and } \\
\text { micafungin: } \\
\text { R: } 0.55 \%\end{array}$ & & & [112] \\
\hline & Poland & 81 & $\begin{array}{l}\text { Fluconazole: } \\
\text { R: } 22.2 \% \\
\text { ISDD: } 77.7 \% \\
\text { Fluconazole and } \\
\text { voriconazole: } \\
\text { R: } 1.2 \% \\
\text { Voriconazole } \\
\text { R: } 7.4 \% \\
\text { Cross-Resistance to } \\
\text { other azoles: } \\
\text { R: } 18.5 \%\end{array}$ & $\begin{array}{l}\text { Caspofungin, } \\
\text { anidulafungin and } \\
\text { micafungin: } \\
\text { S: } 100 \%\end{array}$ & $\begin{array}{l}\text { Amphotericin B: } \\
\text { S: } 100 \% \\
\text { 5-fluorocytosine: } \\
\text { S: } 93.8 \% \\
\text { ISDD: } 3.7 \% \\
\text { R: } 2.5 \%\end{array}$ & & [113] \\
\hline
\end{tabular}


Table 1. Cont.

\begin{tabular}{|c|c|c|c|c|c|c|c|}
\hline \multirow{2}{*}{ Continent } & \multirow{2}{*}{ Country } & \multirow{2}{*}{ Number of Strains } & \multicolumn{4}{|c|}{ Susceptibility and Resistance } & \multirow{2}{*}{ References } \\
\hline & & & Azoles & Echinocandins & Polyenes & Other & \\
\hline & $\begin{array}{l}\text { Poland, France, } \\
\text { Greece, Germany, } \\
\text { Italy, Czech Republic, } \\
\text { Spain, Austria, } \\
\text { Serbia, Iran, India, } \\
\text { Thailand, United } \\
\text { States }\end{array}$ & 64 & $\begin{array}{l}\text { Fluconazole: } \\
\text { R: } 1.6 \% \\
\text { Itraconazole: } \\
\text { R: } 1.6 \% \\
\text { Isavuconazole } \\
\text { S: } 100 \% \\
\text { Posaconazole: } \\
\text { R: } 3.1 \% \\
\text { Voriconazole } \\
\text { R: } 3.1 \%\end{array}$ & $\begin{array}{l}\text { Caspofungin, } \\
\text { anidulafungin and } \\
\text { micafungin } \\
\text { S: } 100 \%\end{array}$ & $\begin{array}{l}\text { Amphotericin B: } \\
\text { S: } 100 \% \\
\text { 5-fluorocytosine: } \\
\text { S: } 100 \%\end{array}$ & & {$[114]$} \\
\hline & $\begin{array}{l}\text { Germany } \\
\text { Spain }\end{array}$ & $\begin{array}{l}4 \\
1\end{array}$ & $\begin{array}{l}\text { Fluconazole: } \\
\text { R: } 100 \% \\
\text { Voriconazole: } \\
\text { R: } 100 \%\end{array}$ & & $\begin{array}{l}\text { Amphotericin B: } \\
\text { R: } 100 \%\end{array}$ & & [115] \\
\hline & Jerusalem & 176 & $\begin{array}{l}\text { Fluconazole: } \\
\text { ISDD: } 81.25 \% \\
\text { R: } 4 \% \\
\text { Voriconazole: } \\
\text { R: } 4.7 \%\end{array}$ & $\begin{array}{l}\text { Caspofungin: } \\
\text { R: } 33.6 \%\end{array}$ & $\begin{array}{l}\text { Amphotericin B } \\
\text { S: } 100 \%\end{array}$ & & {$[11]$} \\
\hline Oceania & Australia & 35 & $\begin{array}{l}\text { Fluconazole: } \\
\text { R: } 22.8 \%\end{array}$ & $\begin{array}{l}\text { Caspofungin: } \\
\text { R: } 17.1 \%\end{array}$ & & & [3] \\
\hline
\end{tabular}




\subsection{Susceptibility Variations per Continent}

The study conducted by Tsega et al., in 2019, in Ethiopia, Africa, reported 17 C. glabrata strains isolated from pregnant women. In this study, all strains were sensitive to fluconazole. However, 2 exhibited resistances to clotrimazole, 13 to itraconazole, and 7 to ketoconazole [14]. In Cameroon, Ngouana et al., in 2019, analyzed C. glabrata strains obtained from mucous membranes of HIV-infected patients. Thirty-three C. glabrata strains were isolated with one being resistant to fluconazole (CMI $=0.25-64 \mu \mathrm{g} / \mathrm{mL})$ [104]. In Ghana, Waikhom et al., in 2020, analyzed clinical isolates obtained from 176 pregnant patients. Only 54 patients were diagnosed with Candida infection with positive isolates (44 symptomatic and ten asymptomatic). C. glabrata was isolated in 25 symptomatic women and six asymptomatic women, being the most common isolation with $57.4 \%$. Six C. glabrata isolates were susceptible to fluconazole $(19.4 \%), 13$ were susceptible dose-dependently $(41.9 \%)$, and 12 were resistant (38.7\%). No C. glabrata isolate was susceptible to nystatin, 27 were susceptible dose-dependently $(87.1 \%)$, and 4 were resistant $(12.9 \%)$. Seventeen strains were susceptible to voriconazole (54.8\%), three susceptible dose-dependently $(9.7 \%)$, and eleven strains were resistant (35.5\%) [105].

In the American continent, Fuller et al. reported the isolation of 392 C. glabrata strains in Canada, of which $87.8 \%$ were dose-dependently susceptible to fluconazole with a minimum inhibitory concentration (MIC) of $\leq 4 \mathrm{mg} / \mathrm{mL}$ [37]. In the U.S.A., it has been observed that infections produced by C. albicans have decreased, while those caused by C. glabrata have increased up to $25 \%$ from the Candida non-albicans infections [100]. In South America, there are reports from Chile and Brazil regarding the C. glabrata complex. In Chile, Santolaya et al. reported 37 cases of candidemia generated by C. glabrata; from which $6.6 \%$ were resistant to fluconazole, $20 \%$ to itraconazole, $10 \%$ to micafungin (two strains with MIC values $=0.25 \mu \mathrm{g} / \mathrm{mL}$ and one strain with MIC $=0.5 \mu \mathrm{g} / \mathrm{mL}$ ), and $6.6 \%$ had elevated ECV values for amphotericin B [16]. Similarly, Savastano et al. studied 38 C. glabrata strains obtained from different surfaces in a hospital environment in Brazil and performed susceptibility tests on 8 strains. In all cases, $100 \%$ were sensitive to amphotericin B and nystatin, $50 \%$ were resistant to fluconazole, and $12.5 \%$ were resistant to miconazole [51].

In Asia, many of the existing studies on antifungal resistance to antibiotics shown by the $C$. glabrata complex have been conducted. In China, $\mathrm{Li}$ et al. conducted a retrospective case-control study in which six strains from the C. glabrata complex were tested for antifungal susceptibility, observing the following values: Flucytosine $(\leq 4 \mu \mathrm{g} / \mathrm{mL})$, amphotericin $B$ $(\leq 0.5 \mu \mathrm{g} / \mathrm{mL})$, fluconazole $(4-8 \mu \mathrm{g} / \mathrm{mL})$, itraconazole $(0.125-0.5 \mu \mathrm{g} / \mathrm{mL})$, and voriconazole $(\leq 0.06-0.5)$ [103]. Subsequently, the same working group reported that cancer patients with infections caused by dose-dependently susceptible strains of the $C$. glabrata complex that were given initial monotherapy with azoles were linked to worse outcomes [104]. Likewise, Zeng et al. isolated 73 C. glabrata strains from which $11 \%$ were resistant to flucytosine (MIC $\leq 0.25$ to $>8 \mu \mathrm{g} / \mathrm{mL}$ ), $6.8 \%$ to voriconazole (MIC $\leq 0.062$ to $>8 \mu \mathrm{g} / \mathrm{mL}$ ), $6.8 \%$ to fluconazole (MIC $\leq 0.25$ to $>8 \mu \mathrm{g} / \mathrm{mL}$ ), and $100 \%$ of the isolated strains were resistant to amphotericin $\mathrm{B}[20]$.

In India, there are studies with different results regarding the antifungal sensitivity exhibited by the C. glabrata complex. In a study conducted by Jain et al., $100 \%$ of the 21 C. glabrata strains analyzed showed MIC values within the ranges of antifungal sensitivity [21]. On the other hand, Pote et al. isolated 22 C. glabrata strains from clinical samples obtained from three hospitals that showed resistance to clotrimazole, fluconazole, itraconazole, ketoconazole, and nystatin [70]. In Nepal, Subramanya et al. analyzed the antifungal susceptibility of nine C. glabrata isolated strains. They found that all strains were susceptible to caspofungin (MIC $\leq 4 \mu \mathrm{g} / \mathrm{mL}$ ) and had intermediate sensitivity to amphotericin B (MIC $=8-16 \mu \mathrm{g} / \mathrm{mL}$ ). As for fluconazole, only six strains were susceptible $(\mathrm{MIC} \leq 4 \mu \mathrm{g} / \mathrm{mL}$ ), one showed intermediate sensitivity (MIC $=8-16 \mu \mathrm{g} / \mathrm{mL}$ ), and two were resistant (MIC $\geq 32 \mu \mathrm{g} / \mathrm{mL}$ ). Regarding voriconazole, eight strains had intermediate sensitivity and one was resistant to this antifungal [95]. 
Alobaid et al. isolated 11 C. glabrata strains from a second-level hospital in Kuwait that showed variable antifungal susceptibility to fluconazole. The authors reported that $64 \%$ of these strains were resistant ( $\mathrm{MIC}=64 \mu \mathrm{g} / \mathrm{mL}$ ) and $36 \%$ were dose-dependently susceptible $(\mathrm{MIC}=32 \mu \mathrm{g} / \mathrm{mL})$ [107]. Conversely, Al-Baqsami et al. found that $48 \%$ (36 strains) of the 75 C. glabrata sensu stricto strains isolated in Kuwait were resistant (MIC $>32 \mu \mathrm{g} / \mathrm{mL}$ ) to fluconazole and 52\% (39 strains) were dose-dependently susceptible (MIC $\leq 32 \mu \mathrm{g} / \mathrm{mL}$ ). In addition, five strains presented resistance to micafungin (MIC $>0.125 \mu \mathrm{g} / \mathrm{mL}$ ) (three were resistant and two were dose-dependently susceptible), four showed resistance to caspofungin (MIC of $\geq 0.5 \mu \mathrm{g} / \mathrm{mL}$ ), and five strains were resistant to amphotericin $B$ $(\mathrm{MIC}>1 \mu \mathrm{g} / \mathrm{mL})$ [108].

Gülmez et al. studied several cases of fungemia in Turkey, isolating 12 C. glabrata strains resistant to fluconazole [109]. Moreover, Kaan et al. identified 83 C. glabrata strains, from which $45.8 \%$ were resistant to itraconazole, $9.2 \%$ to fluconazole, and $43.4 \%$ to voriconazole [71].

Similarly, in Europe, Marin et al. reported in Spain that all isolates from this complex were dose-dependently susceptible to fluconazole [101]. Likewise, Ryan et al. isolated 21 C. glabrata strains in Ireland, of which $37 \%$ showed resistance to fluconazole and $14 \%$ to amphotericin B [5]. Sikora et al. isolated 445 C. glabrata sensu lato strains in Poland, from which 24 were identified as $C$. nivariensis. It was observed that all strains had an intermediate sensitivity to fluconazole (MIC $=0.25-256 \mathrm{mg} / \mathrm{L}$ ), 41\% were resistant to itraconazole $(\mathrm{MIC}=1.5-32 \mathrm{~m} / \mathrm{L}), 50 \%$ were resistant to posaconazole $(\mathrm{MIC}=1.5-32 \mathrm{mg} / \mathrm{L})$, and $83 \%$ were susceptible to voriconazole $(\mathrm{MIC}=0.008-2.0 \mathrm{mg} / \mathrm{L})$. All strains were susceptible to echinocandins and amphotericin B [57]. In Greece, from 2009 to 2018, Siopi et al. reported multidrug resistance in $\mathrm{C}$. glabrata as a major concern; however, no specific mechanism was reported [24]. Furthermore, from a multihospital study, Aldejohann et al. reported resistance in the C. glabrata complex to several drugs including echinocandins, probably related to gene regulation; specifically, those linked to glucan synthase expression [110]. Similarly, Coste et al. observed resistance to echinocandins linked to the FKS-genes mutation in Switzerland [111]. However, other authors, such as Fraser et al., suggest that resistance is a rare phenomenon in some countries like the United Kingdom [112]. A multicenter study showed the relevance of $C$. glabrata in yeast infections with mixed agents and suggested a potentiation of resistance in those cases [114]. In Jerusalem, Israel et al. examined C. glabrata strains that exhibited a susceptible-dose-dependent pattern to fluconazole with MIC values $\leq 32 \mu \mathrm{g} / \mathrm{mL}[11]$.

An epidemiological study conducted in Australia by Boan et al. reported that $22.8 \%$ $(8 / 35)$ of the C. glabrata complex isolated strains were resistant to fluconazole and $17.1 \%$ $(6 / 35)$ were not sensitive to caspofungin. It was also reported that the prevalence of this complex has been increasing [3].

\subsection{Drug Resistance Fluctuations Caused by the Type of Candida and Genetic Variations}

The mechanisms of antifungal resistance in the C. glabrata complex are still being thoroughly studied (Table 2) [116]. As mentioned above, the C. glabrata complex has shown drug resistance to the azoles in several cases, which act by inhibiting the 14- $\alpha$ lanosterol demethylase that is encoded by the ERG11 gene. The ERG11 gene is known to participate in ergosterol biosynthesis [97,117]. Interestingly, Hull et al. 2012 found that the isolate of C. glabrata (CG156) has an ERG11 mutation that induces a loss of function associated with cross-resistance to azoles and polyenes. This isolate exchanges ergosterol from the membrane for other sterols such as lanosterol and fecosterol, among others [115].

Various reports have found that antifungal-resistant C. glabrata strains have mutations associated with the Pdr1 transcription factor and the overexpression of the ABC-type efflux pumps (ATP-Binding Cassette), mainly CDR1 and CDR2 (Candida Drug Resistance) [8,118-120]. Such pumps can translocate small molecules to the outside of the cell and are regulated by the TAC1 transcription factor $[121,122]$. 
Several mutations have been identified in the PDR1 zinc-cluster-containing transcription factor in the C. glabrata complex that favor the overexpression of the CDR1, CDR2, SNQ2, and PDH1 transporters, which are known to carry multiple drugs [117-120,123]. For example, Hou et al. observed that 14 C. glabrata isolated strains with polymorphisms in PDR1 showed increased resistance to fluconazole (MIC $\geq 64 \mu \mathrm{g} / \mathrm{mL}$ ) [124]. On the other hand, Culakova et al. noted that the deletion of PDR1 decreases cell surface hydrophobicity during biofilm formation, which increases the susceptibility of these mutant strains to different azoles such as fluconazole, bifonazole, itraconazole, ketoconazole, clotrimazole, and miconazole [125]. Likewise, the activation of azole transporters CDR1 and CDR2, alone or in combination, has been associated with antifungal resistance in C. glabrata [8]. Farahyar et al. reported that $C$. glabrata strains have drug-resistant Candida genes $(C g C D R) C g C D R 1$ and $C g C D R 2$, as well as Fatty Acid Activator 1 (FAA1), which are positively regulated twice as much in resistant strains. These results demonstrated that the overexpression of these three genes is associated with azole resistance by modifying the biological transport pathways of hydrophobic compounds and the lipid metabolism in C. glabrata [126]. Szweda et al. demonstrated through real-time PCR studies that 13 of 15 azole-resistant strains displayed upregulation of the CDR1 gene encoding the efflux pump. Conversely, no upregulation of the CDR2 expression or ERG11 gene was observed [113]. In addition, the mitochondrial dysfunction associated with the formation of "small mutants", deficient in mitochondrial DNA, positively regulates the $\mathrm{ABC}$ transporter genes, increasing resistance to these drugs $[64,120,124]$.

Another factor associated with drug resistance in C. glabrata is $A D A 2$ [64]. $A D A$ is a component that serves as a transcription adapter of the Spt-Ada-Gen5 acetyltransferase complex (SAGA complex), previously found in C. albicans and determined to be necessary for tolerance and virulence of antifungal drugs. Shi et al. and Yu et al. observed various roles that $A D A 2$ has in cellular functions such as growth, cell wall integrity, antifungal tolerance, and suppression of virulence in the $C$. glabrata complex $[64,127]$. Yu et al. reported that $A D A 2$ is involved in thermotolerance, finding that mutations on C. glabrata ADA2 $(C g A D A 2)$ generate severe defects in the growth of strains at $40^{\circ} \mathrm{C}$, and intermediate defects at $37^{\circ} \mathrm{C}$ and $25^{\circ} \mathrm{C}$. It also increases the susceptibility of $C$. glabrata towards azoles, echinocandins, and polyenes. However, the authors also reported that the deletion of CgADA2 resulted in hypervirulence of the strains in an in vivo murine model, possibly due to the positive regulation of adherence factors in strains [127].

Since most $C$. glabrata strains are resistant to azoles, a therapeutic measure that has shown some effectiveness is echinocandins. Drugs such as anidulafungin, caspofungin, and micafungin inhibit the glucan synthase enzyme [128]. These drugs inhibit the formation of $\beta-1,3$-D glucan by non-competitively binding to the $F k s 1 p$ and $F k s 2 p$ subunits of the $\beta-1,3$ glucan synthase. As the $\beta-1,3-\mathrm{D}$ glucan is an integral part of the structure and function of the fungal cell wall, the inhibition of its formation generates high permeability of the cell wall and thus cell lysis [61,108,111,129]. However, increased drug resistance to these drugs has been seen in the C. glabrata complex due to previous exposure to these antifungals $[111,130]$. Resistance to these drugs comes from specific mutations that lead to amino acid substitutions in two different regions of these genes (hotspots 1 and 2 or (HS1 and HS2)), altering the conformation of the Fks1p and Fks2p subunits, thus lowering affinity to echinocandins [108]. Pan-resistance to these antifungals in C. glabrata has a prevalence range of 2-13\% [111,131]. In Switzerland, Coste et al. identified five candidemia cases by C. glabrata previously exposed to echinocandins and resistant to this drug. After a molecular study, the authors found that drug resistance in three strains was associated with mutation S663P in FKS2, mutation S629P in FKS1 in one strain, and F659 in FKS2 in another one [111]. However, the presence of FKS gene mutations in C. glabrata isolates is not always associated with phenotypic resistance in vitro [132]. In this regard, in 2012, Katiyar et al. demonstrated that even when Fks1 and Fks2 have the same functionality, the redundancy of $F k s 1-F k s 2$ attenuates the resistance rate and the impact of mutations that confer resistance to echinocandins [133]. 
Table 2. Drug resistance fluctuations caused by the type of Candida and genetic variations.

\begin{tabular}{|c|c|c|c|c|c|c|}
\hline \multirow{2}{*}{ Yeast } & \multirow{2}{*}{\multicolumn{2}{|c|}{ Drug on Which Resistance Is Generated }} & \multicolumn{3}{|c|}{ Antifungal Resistance } & \multirow{2}{*}{ References } \\
\hline & & & Genes and Proteins Involved & Mechanisms Involved & Result & \\
\hline \multirow{7}{*}{ Complex C. glabrata } & \multirow{3}{*}{ Azoles } & \multirow{3}{*}{ Multiple drugs } & \multirow{3}{*}{$\begin{array}{l}\text { Mutations (polymorphisms, } \\
\text { deletions, etc.) in the } P d r 1 \text { gene } \\
\text { of the PDR1 transcription factor } \\
\text { and TAC1 transcription factor }\end{array}$} & \multirow{4}{*}{$\begin{array}{l}\text { Overexpression and activation } \\
\text { of ATP-binding cassettes } \\
\text { [CDR1, CDR2 (also designated } \\
\text { PDH1, SNQ2, FAA1)] }\end{array}$} & $\begin{array}{l}\text { Drugs transported to the } \\
\text { outside of the cell }\end{array}$ & {$[8,113,117-124,126]$} \\
\hline & & & & & $\begin{array}{l}\text { Decreased cell surface } \\
\text { hydrophobicity during } \\
\text { biofilm formation }\end{array}$ & [125] \\
\hline & & & & & $\begin{array}{l}\text { Modification of biological } \\
\text { transport pathways of } \\
\text { hydrophobic compounds and } \\
\text { lipid metabolism }\end{array}$ & [126] \\
\hline & Azoles & & $\begin{array}{l}\text { Mitochondrial dysfunction } \\
\text { associated with the } \\
\text { development of mitochondrial } \\
\text { DNA-deficient } \\
\text { "small mutants." }\end{array}$ & & $\begin{array}{l}\text { Drugs transported to the } \\
\text { outside of the cell }\end{array}$ & {$[64,120,124]$} \\
\hline & Azoles & & Deletion of $C g A D A 2$ & $\begin{array}{l}\text { Positive regulation of } \\
\text { adherence factors }\end{array}$ & $\begin{array}{l}\text { Thermotolerance and } \\
\text { hypervirulence }\end{array}$ & [127] \\
\hline & Echinocandins & & $\begin{array}{c}\text { Mutations in FKS1 and FKS2 in } \\
\text { the hot spots HS1 and HS2 } \\
\text { (Examples: FKS1 S629P, FKS2 } \\
\text { F659 FKS2 S663P y) }\end{array}$ & $\begin{array}{l}\text { Altered conformation of the } \\
\text { 1,3- } \beta \text {-glucan-synthase subunits } \\
\text { Fks1p and Fks2p }\end{array}$ & $\begin{array}{l}\text { Reduced affinity of } \\
\text { echinocandins for } \beta-1,3 \text { glucan. }\end{array}$ & {$[108,110,111,129-133]$} \\
\hline & \multicolumn{2}{|l|}{ Azoles/polyenes } & $\begin{array}{l}\text { Mutations in the ERG6 and } \\
\text { ERG11 proteins }\end{array}$ & $\begin{array}{l}\text { Alteration of sterol } \\
\text { 14- } \alpha \text {-demethylase }\end{array}$ & $\begin{array}{l}\text { Ergosterol exchanged for } \\
\text { generated exogenous sterols }\end{array}$ & [115] \\
\hline \multirow[t]{2}{*}{ C. nivariensis } & \multirow{2}{*}{\multicolumn{2}{|c|}{ Azoles }} & $\begin{array}{l}\text { Increased expression of YPS1, } \\
\text { AWP3, EPA1, ERG11, CDR1, } \\
\text { and CDR2 genes }\end{array}$ & & $\begin{array}{l}\text { Antifungal resistance and } \\
\text { increased virulence }\end{array}$ & {$[86]$} \\
\hline & & & $\begin{array}{c}\text { Increased mRNA expression of } \\
\text { ERG11, CDR1, and CDR2 }\end{array}$ & $\begin{array}{l}\text { Overexpression and activation } \\
\text { of CDRs }\end{array}$ & Increased antifungal resistance & [102] \\
\hline
\end{tabular}


Another important gene in the generation of antifungal resistance is the ERG6 as it intervenes in the integrity of the cell wall and the pharmacological tolerance in these yeasts [64]. Vandeputte et al. reported that a C. glabrata isolate with a missense mutation in the ERG6 gene had a lower ergosterol content associated with its biosynthesis pathway, causing cell wall modifications and increased susceptibility to drugs acting on the cell wall [134].

Vacuolar proton-translocating ATPases (V-ATPases) are present in the vacuolar membranes of fungi. They regulate many cellular processes and keep ionic homeostasis by maintaining acidic $\mathrm{pH}$ inside the fungal cell. Minematsu et al. conducted a study where they observed that when removing the VPH2 gene and interrupting the V-ATPase function, the response of $C$. glabrata is altered causing decreased virulence and homeostasis alteration of the vacuolar $\mathrm{pH}$. Therefore, it is assumed that $V P H 2$ deletion may increase susceptibility to antifungals [135]. Accordingly, Roetzer et al. demonstrated in 2008 that the protein $V P H 2$, required for vacuolar $\mathrm{H}^{+}$-ATPase function, was widely induced under different oxidative stress conditions in C. glabrata strains. These studies allow us to understand that, when subjected to certain conditions, the $C$. glabrata strains can induce the expression of this protein to maintain the internal $\mathrm{pH}$ of the cell and preserve its virulence [136].

\subsection{Drug Resistance Variations in C. Glabrata Complex Species}

Reports indicate that in the same way there are differences in the virulence factors among the C. glabrata complex species, there are also differences in their antifungal resistance. For example, reports show that $C$. glabrata sensu stricto is more susceptible to fluconazole, itraconazole, and voriconazole than C. nivariensis $[62,63,92]$.

López et al. and Fujita et al. reported catheter-associated candidemia resistant to empirical treatment with fluconazole caused by $C$. nivariensis. When conducting susceptibility tests to various antifungals in blood cultures, it was observed that, in these cases, treatments with echinocandins (caspofungin and micafungin) and flucytosine were the most appropriate because of their sensitivity [118,137].

According to Shi et al., the C. nivariensis strains presented a higher MIC than C. albicans. They also showed increased expression of virulent and resistant genes such as YPS1, AWP3, EPA1, ERG11, CDR1, and CDR2 than C. glabrata sensu stricto isolates [64]. In addition, in patients with vulvovaginal candidiasis caused by $C$. nivariensis, a low cure rate was observed using conventional antifungals [64].

Accordingly, in the study conducted by Shi et al., it was observed that the mRNA expression of ERG11, CDR1, and CDR2 was higher in isolates of $C$. nivariensis strains than C. glabrata sensu stricto. These results are linked to C. nivariensis strains' drug resistance [64]. However, Arastehfar et al. showed that the $C$. nivariensis strains obtained from clinical isolates were sensitive to azoles, polyenes, and echinocandins [106].

In turn, Kaur et al. and Sikora et al. showed that the YPS gene's deletion or mutations cause decreased virulence in C. glabrata $[138,139]$. Currently, there is no evidence on the prevalence of YPS in C. nivariensis and little is known about its antifungal susceptibility [140].

Regarding C. bracarensis, Małek et al. performed in vitro susceptibility tests of different antifungals in isolates obtained by PCR from a group of 353 strains of the C. glabrata complex, evidencing drug resistance to various azoles (fluconazole, itraconazole, and posaconazole), amphotericin B, and flucytosine. They also reported sensitivity to echinocandins (anidulafungin and caspofungin) [58].

\section{Virulence Factors}

Virulence factors are important for the pathogenicity of Candida spp., as they allow colonization, adhesion, invasion, and dissemination in tissues. They also help evade the host's defenses to cause infection [63,141-143]. 
Enzymatic activity is considered an important virulence factor in Candida spp. [144]. However, this type of yeast usually expresses virulence factors in different degrees, according to the species. Moreover, as mentioned previously, its expression may depend on the isolate geographical origin, type of infection, site of infection, and the host's reaction [145].

Among the virulence factors used by the C. glabrata complex are biofilm formation and the production of hydrolytic enzymes such as proteases, phospholipases, and hemolysins, which contribute to the adherence, cellular damage, and tissue invasion in the host $[65,143,146-148]$. In addition, they can form a germ tube and they possess phenotypic and genotypic variability [142]. Such virulence factors grant them the ability to evade the host's immune response and generate antifungal resistance [147,149].

Among the virulence factors reviewed in this work are those involved in the adherence and biofilm formation mechanisms (Figure 2).

\section{Adherence Mechanisms}

The adherence mechanism is an important virulence factor that is regulated by diverse genes and marks the beginning of infection by Candida spp. [150]. Adhesion to host cells is essential for any commensal pathogen, as it allows a firm adherence and avoiding being dragged for elimination [151]. Therefore, it is relevant for the establishment and persistence of the disease [146]. C. albicans and C. glabrata have independently developed specific adhesins, requiring specific or non-specific receptors, as well as various host signals. When the "host" environment is detected, an expression of adhesins occurs that allows binding to the cell receptor [151].

It has been observed that various factors of the environment in which it is located favor adherence of the C. glabrata complex to host cells. Among them is increased acidity in the environment and extracellular polymer production by bacteria located in the oral mucosa of patients using dental prostheses. In other cases, elevated levels of estrogen and glycogen in vaginal secretions during pregnancy provide a carbon-rich nutritional source for these yeasts. Likewise, other studies suggest that the presence of $C$. albicans seems to improve $C$. glabrata complex strains' adherence by injuring mucous membranes and moderately rough and hydrophobic surfaces that create a favorable niche for the microorganism colonization [150-153].

The hydrophobic cell wall of C. glabrata is the place where the physicochemical interactions between the yeast and the colonized region occur. The wall has a surface layer composed of glycoproteins that contributes to host cell recognition and contains various chitin and glucan chains extended along the entire cell wall structure. They present a $\beta$-(1,3)-glucan, $\beta$-(1,6)-glucan branched and bound to chitin by a $\beta$-(1,4)-glucan bond, as well as various adhesin-type cell wall proteins (CWP) [150,154-159].

Epithelial adhesins, or Epa proteins, are the main cell surface proteins involved in C. glabrata virulence $[65,154,160]$. Epa proteins are analogous to Als proteins in C. albicans and thus are important for the adherence mechanism. Epa genes are responsible for encoding these proteins $[39,146,156,161]$. Gabaldon et al. [162] identified an expansion of the Epa gene family that only appears in the three pathogenic species of the Nakaseomyces clade: C. glabrata, C. nivariensis, and C. bracarensis.

There is great variability in the number of Epa genes among C. glabrata complex isolates. It is considered that this gene family is composed of 17 to 23 members, depending on the isolate. Sequencing of the CBS138 C. glabrata strain revealed the presence of 18 genes, while the BG2 strain only has 23 Epa genes. C. bracarensis shows 12 genes and C. nivariensis only 9; while the non-pathogenic strain Nakaseomyces delphensis only has one Epa adhesin. Therefore, Epa genes are vital virulence factors in the C. glabrata complex [39,50,85,152,158], and their presence could explain the highly pathogenic potential observed in C. nivariensis and C. bracarensis $[78,162]$. 


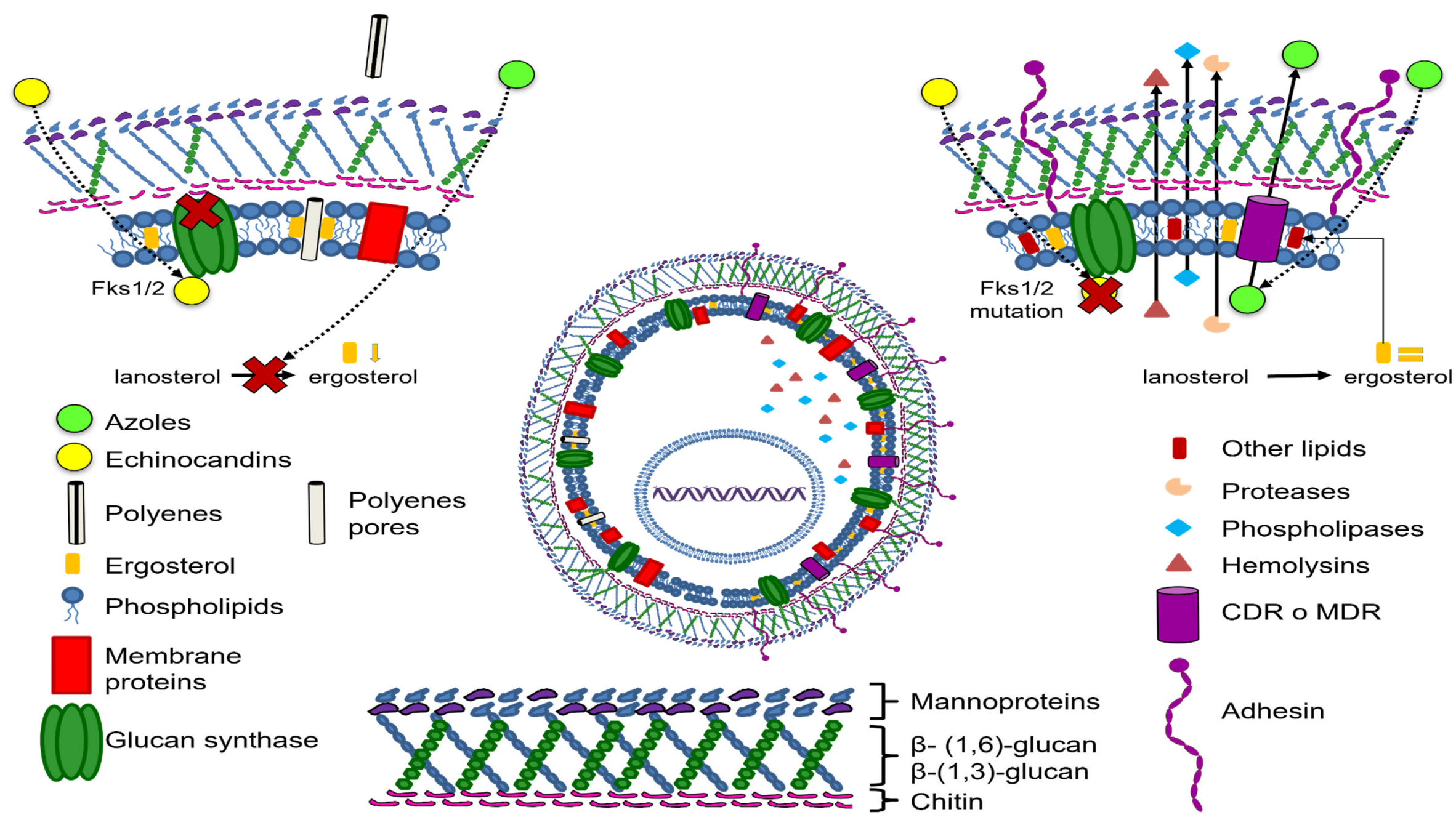

Figure 2. Candida glabrata drug resistance and virulence mechanisms. 
Epithelial adhesin 1 (Epa1) has been identified as the only one needed for C. glabrata to bind to the epithelial surface of the host in vitro as it regulates the interaction between yeast and the host's epithelial cells [158]. In addition, it is involved in biofilm formation [163] and participates in the adherence mechanism in immunological, endothelial, and epithelial cells. It is activated by proteolysis through C. glabrata yapsins ( $\mathrm{CgY}(p s)$, a family of glycosylphosphatidylinositol aspartyl proteases involved in protein maturation and cell wall remodeling, maintenance, and preservation. This type of yapsins (YPS) is encoded by the twelve CgYPS genes [158,164].

In vitro studies have shown that Epa1 gene deletion reduces adhesion to host epithelial cells, suggesting it has a crucial role in fungal adhesion to abiotic substrates [78]. It has also been observed to be regulated by the $P d r 1$ transcription factor $[65,118,142,158,165]$.

The EPA6 and EPA7 genes are functional adhesins present in upper and lower urinary tract infections. Although the EPA6 gene has not been expressed in in vitro studies, it has been observed during urinary tract infections $[48,63,65,164]$. This contributes to the hypothesis that $C$. glabrata can adapt to adverse environmental conditions improving its adherence due to these genes $[48,63,65,164]$.

Epa gene expression is complex and is regulated by subtelomeric silencing based on chromatin and transcriptional factors. Subtelomeric silencing is composed of the SIR complex (Sir2, Sir3, and Sir4), which requires NAD+ as a cofactor, Rap1 that recruits the SIR complex, as well as Rif1, yKu70, and $y K u 80$, which may respond to various environmental factors $[85,154,156,158,166]$.

Moreover, certain proteins have been identified in C. glabrata, such as Pwp7p and Aed1p, that are relevant for adherence in endothelial cells and are not observed in S. cerevisiae nor C. albicans. Such proteins are anchored to glycosylphosphatidylinositol (GPI), and it has been observed that the genes encoding their synthesis regulate the ability of $C$. glabrata to adhere to the epithelial tissue after facilitating binding to carbohydrates present in the host cell. Therefore, they are relevant for yeast virulence $[150,154,156]$. One study showed that the adherence was reduced by $66 \%$ in isolates with a mutation in the Pwp $7 p$ protein, and those with an Aed1p mutation had a 50\% reduction in their adherence capacity [167].

The adherence capacity of $C$. glabrata complex yeasts is relevant for the development and persistence of infections in humans as it leads to biofilm formation on biotic surfaces and, especially, on abiotic ones [67,163]. Figueiredo-Carvalho et al. [168] noted that $C$. nivariensis adheres to inert surfaces, showing a predilection for polystyrene. Other studies have shown that $C$. glabrata has a greater tendency to adhere to acrylic surfaces in dentures, predisposing patients who need to wear them to suffer from oral candidiasis [169]. Furthermore, as already mentioned, this yeast has a greater adherence capacity to urinary epithelium cells compared to other Candida non-albicans species [170]. Nonetheless, Vieira de Melo et al. [171] reported seven C. glabrata isolates with low adherence capacity to oral epithelium cells compared to other Candida spp. [171].

\section{Enzymatic Activity}

Hydrolytic enzymes facilitate Candida spp. Adherence, facilitating the yeast's penetration and invasion into the host tissues causing infection [9].

In C. glabrata, the production of hydrolytic enzymes (proteases, phospholipases, and lipases), and their release to the local environment, causes destruction of the host tissues, including skin, vaginal, and oral mucosal membranes [146].

Riceto et al. [142] observed that some C. glabrata isolates lack virulence factors, such as phospholipase, proteinase, and DNAse activity. This coincides with the observations of Mutlu et al. [172], who reported the absence of biofilm formation, phospholipase, proteinase, and esterase activity in two C. glabrata isolates collected in an Intensive Care Unit (ICU) in Turkey. 
In C. bracarensis, the presence of aspartyl protease, phospholipase, hemolysin, and catalase activity has been observed, with no DNAse and coagulase activity [63]. Moreira et al. [173] also reported proteinase and hemolysin activity in this yeast.

\subsection{Proteases/Proteinases/Aspartyl Proteases}

Among the best-known C. glabrata virulence factors are the aspartyl proteases or yapsins that belong to the YPS family and are encoded by 12 genes [139]. These proteins significantly increase the microorganism's ability to survive within human macrophages and play an important role in cell wall remodeling by removing and releasing proteins anchored with glycosylphosphatidylinositol [174,175].

Proteinases allow the colonization and invasion of host tissue through ruptures in mucous membranes, and act by degrading immunological and structural defense proteins $[65,175]$ such as heavy-chain IgG, alpha2-macroglobulin, protein C3, beta-lactoglobulin, lactoperoxidase, collagen, and fibronectin [65]. Likewise, there are studies that demonstrate the proteinases' ability to degrade a protein substrate, thus suggesting their pathogenic role in infections caused by Candida spp. [176].

Swoboda-Kopeć et al. confirmed that the YPS2, YPS4, and YPS6 genes prevailed in most strains of $C$. glabrata isolated from clinical samples, and that the prevalence of the same genes in C. nivariensis was low [56].

Kaur et al. in their study observed that mutant strains of C. glabrata who had YPS gene nominations did not show a virulent phenotype [138].

C. albicans has been shown to be the species with the highest production of proteinases in various studies carried out $[145,148,176]$. Some studies show that $C$. glabrata display activity of an important proteinase, which positions it among third [176] and fourth [145] in activity after species like C. albicans, C. tropicalis, and C. krusei $[145,176]$. Atalay et al. also reported the presence of activity of proteinases in strains of C. glabrata, observing it in $28 \%$ [148], while Subramanya et al. reported strong proteinase activity in one of nine isolates of C. glabrata [95].

Furthermore, there are also studies such as that of Hacioglu et al. (nine isolates) and that of Rossoni et al. (four isolates) that do not report the activity of proteinases in their isolates of $C$. glabrata $[177,178]$. A more recent study by Sriphannam et al. coincides in which the six strains of $C$. glabrata analyzed, did not show a proteinase activity [179]. The study by Barbosa et al. also showed an absence of proteinase activity in 3 of 4 isolates of C. glabrata, where the remaining isolate showed moderate activity [180].

The study carried out by Pereira et al. in a group of 50 healthy patients and another 50 patients with stomatitis and different types of lesions showed that the isolates of C. glabrata from healthy patients (12 isolates) had moderate proteinase activity in $17 \%$, and the remaining $83 \%$ showed no such activity; those from patients with stomatitis ( 24 isolates) and type I lesions showed moderate activity in only $20 \%$, and $80 \%$ were without activity; patients with type II lesions showed moderate activity in $7 \%$ and activity was not observed in $93 \%$; finally, patients with type III lesions showed moderate activity in $50 \%$, while the remaining $50 \%$ did not show proteinase activity, and this indicates that in most isolates of type III lesions, the production of virulence factors was higher than for the rest of the groups [181].

With respect to the other two species of the C. glabrata complex, there are also few studies that evaluate the presence of enzyme activity due to its poor molecular identification. Treviño-Rangel et al. studied the enzymatic activity of $C$. bracarensis, which presented very strong activity of aspartyl proteinase [63]. Moreira et al. also studied the enzymatic activity of three strains of $C$. bracarensis and confirmed that the strain isolated from a central venous catheter in a hospital in the United Kingdom presented proteolytic activity, that is, released proteases (aspartyl proteases) to the culture medium [173]. In the case of C. nivariensis, Tay et al. confirmed the absence of proteinase activity in two strains [182]; however, Figueiredo-Carvalho et al. analyzed one strain of $C$. nivariensis from a runny nose and observed elevated protease activity [168]. Finally, the most recent study conducted by 
Hernando-Ortiz et al. with strains of C. glabrata, C. nivariensis, and C. bracarensis (two strains for each species) showed that none of the strains had proteinase activity [62]. The above observations exposed by the researchers and their working groups indicate that not all strains of this complex present enzymatic activity, with some strains more virulent than others.

\subsection{Phospholipase}

Phospholipases are hydrolytic enzymes with direct action against phospholipids, therefore generating damage to the cell membrane, in addition to potentiating the invasion of the mucosal epithelium in the host $[9,180,183]$. After disruption of the epithelial cell membranes, the tips of the hyphae penetrate the cytoplasm resulting in cell lysis and tissue damage $[9,180,183]$.

Several studies have reported phospholipase activity in species such as C. albicans; however, in C. glabrata, this activity is not frequent [179]. Of the studies carried out to evaluate the activity of phospholipases in the C. glabrata complex, the vast majority conclude the absence of such enzymatic activity $[62,168,176,177,182,184]$. The study conducted by Kumari et al. reported strong enzymatic activity phospholipases in three of its strains corresponding to C. glabrata, which corresponded to $18.75 \%$ of a total of 16 strains from women with vulvovaginal candidiasis in India [185].

Likewise, the study of Pereira et al. evaluated patients with prosthetic stomatitis and varying degrees of injury in healthy individuals. Twelve healthy patients showed a positive culture for C. glabrata, presenting moderate activity of phospholipase in $25 \%$ and strong activity of the same in $75 \%$; the group of patients with stomatitis and type I lesions showed moderate phospholipase activity in $40 \%$ and strong activity in $60 \%$; patients with type II lesions showed moderate and strong activity in $20 \%$ and $80 \%$, respectively, and $100 \%$ of patients with type III lesions showed strong phospholipase activity [181]. Furthermore, another study showed the production of phospholipase in different isolates of Candida spp., of which six of seven belonged to C. glabrata [171].

Kalaiarasan et al. observed that 15/51 (29.41\%) of their Candida spp. isolates showed phospholipase activity; however, only one isolate (4.3\%) corresponded to C. glabrata [145].

A study conducted in Nepal with 71 isolates of Candida spp. showed that only nine of them were C. glabrata (12.67\%), and only three isolates presented phospholipase activity. In Turkey, from 50 isolates, 14 belonged to C. glabrata (28\%), and only 5 strains showed phospholipase activity. Similarly, a study in Turkey with 100 isolates of Candida spp. showed only 9 C. glabrata isolates (9\%) and 3 strains with phospholipase activity $[95,148,178]$.

With respect to $C$. nivariensis and C. bracarensis, the studies conducted have reported an absence of phospholipase activity in both species [62,173]. However, Treviño-Rangel et al. observed very strong activity of phospholipase in C. bracarensis in their study [63].

\subsection{Esterase}

Some studies suggest that the virulence of Candida spp. species is due to the toxic effects caused by both lipases and esterases on host tissues [186]. These proteins act by degrading the ester bonds of cell membranes by increasing cell invasion [138]. The activity of esterases has been observed in very few isolates of the C. glabrata complex, and in some studies, it has not been reported [63,95,145,148,168,178,179].

Kalaiarasan et al. observed that $30.4 \%$ of C. glabrata strains presented esterase activity, compared to C. tropicalis with $66.7 \%$ and C. albicans with $33.3 \%$ [145].

Atalay et al. reported the production of esterase in one of fourteen strains of C. glabrata, with this being the species with the lowest production in that study [148]. Sriphannam et al. showed that two of their six strains tested for C. glabrata had medium-level esterase activity [179]. In the study conducted by Hacioglu et al., they were also only able to identify esterase activity in a strain of C. glabrata [178]. Likewise, the study of Subramanya et al. observed strong activity in three of nine strains of C. glabrata [95]. Studies have reported the absence of esterase activity in both $C$. nivariensis as in C. bracarensis $[63,168]$. 


\subsection{Hemolysin}

Hemolysins present phospholipases type $\mathrm{C}$ activity and affect the membrane of erythrocytes and lymphocytes, generating the rupture of erythrocytes and cellular damage in lymphocytes, facilitating the recovery or extraction of elemental iron present in host cells, allowing the survival and persistence of the microorganism [65,187]. Hemolytic activity tends to be different in different types of Candida spp. [188].

In most of the studies carried out, it has been observed that the species of the C. glabrata complex that usually produce hemolysins in large quantities are $C$. nivariensis and C. bracarensis, since those made in C. glabrata report the absence of such activity. Luo et al. observed that all C. glabrata strains (33 isolates) were able to produce hemolysins in vitro $(100 \%)$, and that the gene of the protein similar to hemolysin (HLP) is related to hemolytic activity in this yeast [189].

There are studies that show that C. glabrata has poor hemolytic activity as well as an inability to import heme efficiently compared to Candida albicans, so it is suggested that C. glabrata depends mainly on the circulating sources of Fe in the host to be able to meet its needs for this micronutrient [190].

Similarly, Kalaiarasan et al. observed the production of hemolysins in $87 \%$ (20/23 strains) of the C. glabrata strains analyzed [145]. Vieira de Melo et al. also reported the production of hemolysins in all strains (7/70 strains) analyzed in their study and observed that the C. glabrata strains had higher production than the C. albicans isolates and other species [171].

The study of Riceto et al. observed that strains of C. glabrata had moderate hemolytic activity [142]; the above matches our most recent study where moderate and strong hemolysin activity was reported in both healthy patients and patients with stomatitis and different types of lesions [181].

A 2016 study showed the absence of hemolysin in a strain of C. nivariensis [168]. However, a more recent study showed that strains of $C$. nivariensis and $C$. bracarensis produced alpha or partial hemolysis, contrary to C. glabrata, which showed gamma hemolysis; that is, there was no hemolysis [62].

In the case of $C$. bracarensis, a study showed that three strains tested had total hemolytic activity when found in a medium of agar sheep's blood enriched with glucose [173]; in another study with a strain of $C$. bracarensis in Mexico, very strong hemolysin activity was also reported [63].

\section{Biofilm Formation}

Species of the genus Candida usually adapt to different environments, forming microbial communities that irreversibly adhere to surfaces (inert material or living tissue) called biofilms [65]. The formation of biofilms in species of Candida is a recent clinical problem and is associated with a higher mortality rate in patients with infections caused by these pathogens $[191,192]$. It is considered to be the most prevalent form of growth in microorganisms [192].

Therefore, the formation of biofilms is one of the most important virulence factors for pathogenicity in species of Candida $[21,147,186]$ and is associated with recurrent infections and treatment failures $[163,193]$. The ability of the isolates of Candida spp. to form biofilms varies according to the species studied [21,163,194-196].

The adhesion mechanism will result in the development of biofilms, which will provide a favorable and protective environment for the growth of the members of the C. glabrata complex [157].

Its formation comprises, in the first place, the adhesion and colonization of an abiotic and / or biotic surface, followed by cell division or proliferation forming a basal layer of anchoring microcolonies, culminating in the maturation of the biofilm that involves the formation of filaments, hyphae, and/or pseudohyphae as well as extracellular matrix production [191]. The extracellular matrix is rich in carbohydrates and proteins (especially in C. glabrata) [173]; it has the function of protecting cells and acting as a barrier against drugs and other substances toxic to the microorganism, keeps nutrients inside to reach 
biofilm cells [191], and contributes to intrinsic resistance to the host's immune system and other environmental alterations [72]. When the biofilm is mature, it has the ability to detach and disperse, [191] and subsequently, it can colonize new sites, thus completing its life cycle [83].

Several studies agree that the formation of biofilms occurs more frequently in species of Candida non-albicans [72,145,171,178,179,185,186,195,197]; however, the production of biofilms by the C. glabrata complex seems to be absent $[148,176]$, but if it does occur, it is usually mild to moderate production $[145,171,197]$ and some studies report that its production increases when it is co-cultivated with species such as C. albicans [163].

It has been observed that the biofilms of C. glabrata consist of a compact monolayer or multilayer that does not form filaments $[65,163,196]$. Kraneveld et al. identified seven Awp adhesins (Awp 1-7) [198], a family of adhesins previously identified by Groot et al. (Awp 1-4) and is suggested to be involved in the first stage of the development of biofilms in C. glabrata [199].

The formation of biofilms has been closely linked to the development of antifungal resistance in the C. glabrata complex $[29,139,192]$ and involves the participation of various genes and the control of their expression by complexes such as Sir (Sir2-Sir4) and Swi/Snf, which in C. glabrata seem to be the basis of regulation for the formation of biofilms [192] since they are involved in adhesion of the pathogen $[167,200]$.

Santos et al. reported in their study that multi-drug resistance transporters (MFS) CgTPO1_1 and CgTPO1_2 are important for virulence of C. glabrata since its deletion was associated with an increase in survival of the Galleria mellonella infection in vivo [201]. The study also found that CgTPO1_2 is positively regulated during biofilm formation [201]. Again, Santos et al. managed to identify that CgTec1 (an ortholog of CaTec1 in C. albicans and the main regulator of its biofilm formation) was necessary for the activation of the transcription of four MFS, CgTPO1_2, CgQDR2, CgTPO4, and CgDTR1, in the early stages of biofilm formation. They concluded that then, the four MFS act to the benefit of the microorganism since their deletion caused a significant decrease in the formation of biofilms in C. glabrata; likewise, it was observed that the delegation of CgDTR1, CgTPO4, and $C g Q D R 2$ increases the potential of the plasma membrane, leading to a decrease in the expression of genes encoding adhesins such as CgALS1 and CgEPA1 during the formation of biofilms, significantly decreasing them [202].

One study showed that the CgFab1, CgVac7, and CgVac14 signaling components for phosphatidylinositol 3,5-bisphosphate $(P I(3,5) P 2)$ genes are important for biofilm formation, cell survival, and virulence of C. glabrata, since strains with mutations in these genes tend to have a defective cell wall and because the impaired vacuolar functions and biofilm formation observed in vitro was diminished [203].

The study of Kalaiarasan et al. reported that C. glabrata was ranked third in terms of biofilm production with seven strains (30.4\%); two of the strains had moderate production, and the remaining five, mild production of biofilms [145]. Although other studies such as Pongrácz et al. also observed increased production of biofilms in Candida non-albicans, only two strains of C. glabrata showed biofilm formation [197]. The data also match what was observed by Sriphannam et al. where C. glabrata corresponded to 33\% biofilm production, of which two had a high production, two were moderate, one was low, and the rest showed no production [179].

The strains analyzed by Vieira de melo et al. showed low production of biofilms corresponding to C. glabrata [171]. In the study of Hacioglu et al., all species of Candida non-albicans formed biofilms; nine of the strains corresponded to C. glabrata [178]. Likewise, Subramanya et al. reported the production of biofilms in six of nine C. glabrata strains analyzed [95].

Gonçalves et al. compared the formation of biofilms of C. albicans and C. glabrata in an acidic environment ( $\mathrm{pH}$ of 4 ) similar to the vaginal environment, as well as a neutral environment. They noted that C. glabrata formed thicker biofilms under an environment with acidic conditions than in a neutral environment (contrary to what was observed 
in C. albicans), which suggests that the microorganism presents an adaptability to the acidic environment of the vagina as another virulence factor, explaining its presence in women with recurrent vulvo-vaginal candidiasis (CVV) [204]. Likewise, they observed a greater number of components of the biofilm matrix (proteins and carbohydrates) under neutral conditions than under acidic conditions, except for a strain of $C$. glabrata where the opposite was observed [204]. The findings coincide with a study conducted by Gonçalves et al., where they analyzed the effect of progesterone and $\beta$-estradiol on the production of biofilms in C. glabrata and C. albicans. They noted that hormones do not influence the generation of biofilms in C. glabrata, but they reduce biofilm formation in C. albicans by more than $65 \%$ [205].

Finally, they suggest that hormones act as environmental signals that promote the protection of Candida spp. [205]. This is related to what Beyer et al. described when they observed that CgHog1, a high-osmolarity glycerol response MAP kinase that contributes to C. glabrata persistence inside mice macrophages, may be the main quantitative determinant of lactic acid stress resistance. Thus, they suggest that $\mathrm{CgHog} 1$ is important for $\mathrm{C}$. glabrata survival in the common vaginal microbiota as it allows it to tolerate different Lactobacillus species [84].

On the other hand, studies such as those from Atalay et al. (9/50 strains) and Yagmur et al. (12/99 strains) do not report biofilm formation in any of the C. glabrata isolates analyzed $[148,176]$.

One study showed that $C$. glabrata can produce a higher biomass of biofilm on silicone surfaces and in the presence of urine, unlike other species [206]. One study found that the biofilm biomass produced by C. glabrata is greater than in C. nivariensis [64]. Moreira et al. demonstrated biofilm production in the three studied C. bracarensis strains, and they all showed differences in their extents [173].

\section{Conclusions}

The various virulence factors and resistance mechanisms to antifungals presented by species of the $C$. glabrata complex contribute to the perfect pathogenic combination that has allowed this yeast to become one of the most frequent agents of candidiasis.

Author Contributions: M.G.F.-D.-L., R.P.-A., R.H.-C. and E.M.-H. designed the study and wrote the manuscript, contributing equally to the accomplishment of the work; R.P.-A., M.A.S.-U., E.D.F.-G. and P.M.-M. contributed to the writing of the manuscript; M.G.F.-D.-L., E.M.-H., C.R.-C., R.A. and E.O.-H. planned, extracted data, wrote, and critically reviewed the manuscript; E.C.-C., I.H.G.-C., V.A.V.-A., M.R.-C. and T.R.-L. wrote and critically reviewed the manuscript. All authors have read and agreed to the published version of the manuscript.

Funding: This research received no external funding.

Institutional Review Board Statement: Not applicable.

Informed Consent Statement: Not applicable.

Data Availability Statement: Not applicable.

Acknowledgments: Víctor Manuel Espinosa-Hernández from the "Instituto Politécnico Nacional (IPN)" for his assistance in the editing the manuscript. The authors thank Shiftext for language editing and proofreading. M.G.F.-D.-L., R.H.-C., M.A.S-U., E.D.F.-G., E.O.-H., P.M.-M., R.P.-A., and E.M.-H. thank the "Consejo Nacional de Ciencia y Tecnología (Conacyt)" for supporting the performance of this article.

Conflicts of Interest: The authors declare no conflict of interest.

\section{References}

1. Bitar, D.; Lortholary, O.; Le Strat, Y.; Nicolau, J.; Coignard, B.; Tattevin, P.; Che, D.; Dromer, F. Population-Based Analysis of Invasive Fungal Infections, France, 2001-2010. Emerg. Infect. Dis. 2014, 20, 1163-1169. [CrossRef] [PubMed]

2. Hu, L.; He, C.; Zhao, C.; Chen, X.; Hua, H.; Yan, Z. Characterization of Oral Candidiasis and the Candida Species Profile in Patients with Oral Mucosal Diseases. Microb. Pathog. 2019, 134, 103575. [CrossRef] 
3. Boan, P.; Gardam, D. Epidemiology and Antifungal Susceptibility Patterns of Candidemia from a Tertiary Centre in Western Australia. J. Chemother. 2019, 31, 137-140. [CrossRef] [PubMed]

4. Medeiros, M.A.; Melo, A.P.; Bento, A.D.; Souza, L.B.; Neto, F.D.; Garcia, J.B.; Zuza-Alves, D.L.; Francisco, E.C.; Melo, A.S.; Chaves, G.M. Epidemiology and Prognostic Factors of Nosocomial Candidemia in Northeast Brazil: A Six-Year Retrospective Study. PLoS ONE 2019, 14, e0221033. [CrossRef]

5. Ryan, P.; Motherway, C.; Powell, J.; Elsaka, A.; Sheikh, A.A.; Jahangir, A.; O'Connell, N.H.; Dunne, C.P. Candidaemia in an Irish Intensive Care Unit Setting between 2004 and 2018 Reflects Increased Incidence of Candida glabrata. J. Hosp. Infect. 2019, 102, 347-350. [CrossRef]

6. Güzel, A.B.; Küçükgöz-Güleç, Ü.; Aydin, M.; Gümral, R.; Kalkanci, A.; Ilkit, M. Candida Vaginitis during Contraceptive Use: The Influence of Methods, Antifungal Susceptibility and Virulence Patterns. J. Obstet. Gynaecol. 2013, 33, 850-856. [CrossRef]

7. Silva, M.G.C.; Rodrigues, G.S.; Gonçalves, I.L.; Grazziotin, N.A. Candida Species Distribution and Fluconazole Susceptibility of Blood Isolates at a Regional Hospital in Passo Fundo, RS, Brazil. Bras. Patol. Med. Lab. 2015, 51, 158-161. [CrossRef]

8. Neves-Junior, A.; Cartágenes-Pinto, A.C.; Rocha, D.A.; Sá, L.F.; Junqueira, M.D.; Ferreira-Pereira, A. Prevalence and Fluconazole Susceptibility Profile of Candida spp. Clinical Isolates in a Brazilian Tertiary Hospital in Minas Gerais, Brazil. An. Acad. Bras. Ciênc. 2015, 87, 1349-1359. [CrossRef] [PubMed]

9. Gonçalves, B.; Ferreira, C.; Alves, C.T.; Henriques, M.; Azeredo, J.; Silva, S. Vulvovaginal Candidiasis: Epidemiology, Microbiology and Risk Factors. Crit. Rev. Microbiol. 2016, 42, 905-927. [CrossRef]

10. Braga, P.R.; Cruz, I.L.; Ortiz, I.; Barreiros, G.; Nouér, S.A.; Nucci, M. Secular Trends of Candidemia at a Brazilian Tertiary Care Teaching Hospital. Braz. J. Infect. Dis. 2018, 22, 273-277. [CrossRef]

11. Israel, S.; Amit, S.; Israel, A.; Livneh, A.; Nir-Paz, R.; Korem, M. The Epidemiology and Susceptibility of Candidemia in Jerusalem, Israel. Front. Cell. Infect. Microbiol. 2019, 9, 352. [CrossRef] [PubMed]

12. Maraki, S.; Mavromanolaki, V.E.; Stafylaki, D.; Nioti, E.; Hamilos, G.; Kasimati, A. Epidemiology and Antifungal Susceptibility Patterns of Candida Isolates from Greek Women with Vulvovaginal Candidiasis. Mycoses 2019, 62, 692-697. [CrossRef]

13. Tarapan, S.; Matangkasombut, O.; Trachootham, D.; Sattabanasuk, V.; Talungchit, S.; Paemuang, W.; Phonyiam, T.; Chokchaitam, O.; Mungkung, O.; Lam-ubol, A. Oral Candida Colonization in Xerostomic Postradiotherapy Head and Neck Cancer Patients. Oral Dis. 2019, 25, 1798-1808. [CrossRef] [PubMed]

14. Tsega, A.; Mekonnen, F. Prevalence, Risk Factors and Antifungal Susceptibility Pattern of Candida Species among Pregnant Women at Debre Markos Referral Hospital, Northwest Ethiopia. BMC Pregnancy Childbirth 2019, 19, 527. [CrossRef]

15. Matic Petrovic, S.; Radunovic, M.; Barac, M.; Kuzmanovic Pficer, J.; Pavlica, D.; Arsic Arsenijevic, V.; Pucar, A. Subgingival Areas as Potential Reservoirs of Different Candida spp. in Type 2 Diabetes Patients and Healthy Subjects. PLoS ONE 2019, 14, e0210527. [CrossRef]

16. Santolaya, M.E.; Thompson, L.; Benadof, D.; Tapia, C.; Legarraga, P.; Cortés, C.; Rabello, M.; Valenzuela, R.; Rojas, P.; Rabagliati, R.; et al. A Prospective, Multi-Center Study of Candida Bloodstream Infections in Chile. PLoS ONE 2019, 14, e0212924. [CrossRef]

17. Alrayyes, S.F.; Alruwaili, H.M.; Taher, I.A.; Elrahawy, K.M.; Almaeen, A.H.; Ashekhi, A.O.; Alam, M.K. Oral Candida Carriage and Associated Risk Indicators among Adults in Sakaka, Saudi Arabia. BMC Oral Health 2019, 19, 86. [CrossRef]

18. Djohan, V.; Angora, K.E.; Vanga-Bosson, A.H.; Konaté, A.; Kassi, K.F.; Kiki-Barro, P.C.M.; Bedia-Tanoh, A.V.; Miezan, S.; Menan, E.I.H.; Yavo, W. Recurrent Vulvo-Vaginal Candidiasis in Abidjan (Côte d'Ivoire): Aetiology and Associated Factors. J. Mycol. Med. 2019, 29, 127-131. [CrossRef] [PubMed]

19. Kim, Y.J.; Kim, S.I.; Choi, J.Y.; Yoon, S.K.; Na, G.H.; You, Y.K.; Kim, D.G.; Kim, M.S.; Lee, J.G.; Joo, D.J.; et al. Invasive Fungal Infection in Liver Transplant Recipients in a Prophylactic Era: A Multicenter Retrospective Cohort Study in Korea. Medicine 2019, 98, e16179. [CrossRef]

20. Zeng, Z.; Tian, G.; Ding, Y.; Yang, K.; Liu, J.; Deng, J. Surveillance Study of the Prevalence, Species Distribution, Antifungal Susceptibility, Risk Factors and Mortality of Invasive Candidiasis in a Tertiary Teaching Hospital in Southwest China. BMC Infect. Dis. 2019, 19, 939. [CrossRef]

21. Jain, A.K.; Misra, V.; Ranjan, N.; Jain, S.B.; Gandhi, S. Speciation, Biofilm Formation and Antifungal Susceptibility of Candida Isolates from Clinically Diagnosed Patient of UTI in a Tertiary Care Hospital. J. Assoc. Physicians India 2019, 67, 42-45. [PubMed]

22. Ghaddar, N.; Anastasiadis, E.; Halimeh, R.; Ghaddar, A.; Dhar, R.; AlFouzan, W.; Yusef, H.; El Chaar, M. Prevalence and Antifungal Susceptibility of Candida albicans Causing Vaginal Discharge among Pregnant Women in Lebanon. BMC Infect. Dis. 2020, 20, 32. [CrossRef]

23. Kumar, A.; Nair, R.; Kumar, M.; Banerjee, A.; Chakrabarti, A.; Rudramurthy, S.M.; Bagga, R.; Gaur, N.A.; Mondal, A.K.; Prasad, R. Assessment of Antifungal Resistance and Associated Molecular Mechanism in Candida albicans Isolates from Different Cohorts of Patients in North Indian State of Haryana. Folia Microbiol. 2020, 65, 747-754. [CrossRef] [PubMed]

24. Siopi, M.; Tarpatzi, A.; Kalogeropoulou, E.; Damianidou, S.; Vasilakopoulou, A.; Vourli, S.; Pournaras, S.; Meletiadis, J. Epidemiological Trends of Fungemia in Greece with a Focus on Candidemia during the Recent Financial Crisis: A 10-Year Survey in a Tertiary Care Academic Hospital and Review of Literature. Antimicrob. Agents Chemother. 2020, 64, e01516-19. [CrossRef] [PubMed]

25. Kord, M.; Salehi, M.; Khodavaisy, S.; Hashemi, S.J.; Daie Ghazvini, R.; Rezaei, S.; Maleki, A.; Elmimoghaddam, A.; Alijani, N.; Abdollahi, A.; et al. Epidemiology of Yeast Species Causing Bloodstream Infection in Tehran, Iran (2015-2017); Superiority of 21-Plex PCR over the Vitek 2 System for Yeast Identification. J. Med. Microbiol. 2020, 69, 712-720. [CrossRef] [PubMed] 
26. Oliver, J.C.; Laghi, L.; Parolin, C.; Foschi, C.; Marangoni, A.; Liberatore, A.; Dias, A.L.T.; Cricca, M.; Vitali, B. Metabolic Profiling of Candida Clinical Isolates of Different Species and Infection Sources. Sci. Rep. 2020, 10, 16716. [CrossRef] [PubMed]

27. Gabaldón, T.; Carreté, L. The Birth of a Deadly Yeast: Tracing the Evolutionary Emergence of Virulence Traits in Candida glabrata. FEMS Yeast Res. 2016, 16, fov110. [CrossRef]

28. Aldardeer, N.F.; Albar, H.; Al-Attas, M.; Eldali, A.; Qutub, M.; Hassanien, A.; Alraddadi, B. Antifungal Resistance in Patients with Candidaemia: A Retrospective Cohort Study. BMC Infect. Dis. 2020, 20, 55. [CrossRef] [PubMed]

29. Rajendran, R.; Sherry, L.; Nile, C.J.; Sherriff, A.; Johnson, E.M.; Hanson, M.F.; Williams, C.; Munro, C.A.; Jones, B.J.; Ramage, G. Biofilm Formation Is a Risk Factor for Mortality in Patients with Candida albicans Bloodstream Infection-Scotland, $2012-2013$. Clin. Microbiol. Infect. 2016, 22, 87-93. [CrossRef]

30. Aguilar, G.; Araujo, P.; Godoy, E.; Falcón, M.; Centurión, M.G.; Ortiz, R.; Britez, M.; Martínez, M. Identification and Characteristics of Candida spp. in Vaginal Secretion of Pregnant and Non-Pregnant Patients. Mem. Inst. Investig. Cienc. Salud 2017, 15, 6-12. [CrossRef]

31. Gülmez, D.; Sı̆̆, A.K.; Akar, N.; Duyan, S.; Arıkan Akdağlı, S. Changing Trends in Isolation Frequencies and Species of Clinical Fungal Strains: What Do the 12-years (2008-2019) Mycology Laboratory Data Tell About? Mikrobiyol. Bul. 2021, 55, 53-66. [CrossRef] [PubMed]

32. Sganga, G.; Wang, M.; Capparella, M.R.; Tawadrous, M.; Yan, J.L.; Aram, J.A.; Montravers, P. Evaluation of Anidulafungin in the Treatment of Intra-Abdominal Candidiasis: A Pooled Analysis of Patient-Level Data from 5 Prospective Studies. Eur. J. Clin. Microbiol. Infect. Dis. 2019, 38, 1849-1856. [CrossRef]

33. Logan, C.; Martin-Loeches, I.; Bicanic, T. Invasive Candidiasis in Critical Care: Challenges and Future Directions. Intensive Care Med. 2020, 46, 2001-2014. [CrossRef]

34. Ambe, N.F.; Longdoh, N.A.; Tebid, P.; Bobga, T.P.; Nkfusai, C.N.; Ngwa, S.B.; Nsai, F.S.; Cumber, S.N. The Prevalence, Risk Factors and Antifungal Sensitivity Pattern of Oral Candidiasis in HIV/AIDS Patients in Kumba District Hospital, South West Region, Cameroon. Pan Afr. Med. J. 2020, 36, 23. [CrossRef]

35. Eghtedar Nejad, E.; Ghasemi Nejad Almani, P.; Mohammadi, M.A.; Salari, S. Molecular Identification of Candida Isolates by Real-time PCR-high-resolution Melting Analysis and Investigation of the Genetic Diversity of Candida Species. J. Clin. Lab. Anal. 2020, 34, e23444. [CrossRef] [PubMed]

36. Thompson, G.R.; Horcajada, J.P.; Locke, J.B.; Viani, R.; Pappas, P.; Ghannoum, M.; Sandison, T.; Soriano, A. 1284. Outcomes by Baseline Pathogens and Susceptibility in the STRIVE Phase 2 Trial of Once-Weekly Rezafungin for Treatment of Candidemia and Invasive Candidiasis Compared with Caspofungin. Open Forum Infect. Dis. 2020, 7, S657-S658. [CrossRef]

37. Fuller, J.; Dingle, T.C.; Bull, A.; Shokoples, S.; Laverdière, M.; Baxter, M.R.; Adam, H.J.; Karlowsky, J.A.; Zhanel, G.G.; Canadian Antimicrobial Resistance Alliance (CARA) and CANWARD; et al. Species Distribution and Antifungal Susceptibility of Invasive Candida Isolates from Canadian Hospitals: Results of the CANWARD 2011-16 Study. J. Antimicrob. Chemother. 2019, 74, iv48-iv54. [CrossRef] [PubMed]

38. Ulrych, J.; Adámková, V.; Matek, J.; Komarc, M.; Frýba, V.; Schmidt, D.; Koželský, P.; Studená, A.; Bříza, J.; Krška, Z. IntraAbdominal Candidiasis in Surgical Intensive Care Unit-Epidemiology Characteristics and Trends. Epidemiol. Mikrobiol. Imunol. 2020, 69, 57-63.

39. Timmermans, B.; De Las Peñas, A.; Castaño, I.; Van Dijck, P. Adhesins in Candida glabrata. J. Fungi 2018, 4, 60. [CrossRef] [PubMed]

40. Li, D.; Li, T.; Bai, C.; Zhang, Q.; Li, Z.; Li, X. A Predictive Nomogram for Mortality of Cancer Patients with Invasive Candidiasis: A 10-Year Study in a Cancer Center of North China. BMC Infect. Dis. 2021, 21, 76. [CrossRef] [PubMed]

41. Ng, T.S.; Desa, M.N.M.; Sandai, D.; Chong, P.P.; Than, L.T.L. Growth, Biofilm Formation, Antifungal Susceptibility and Oxidative Stress Resistance of Candida glabrata Are Affected by Different Glucose Concentrations. Infect. Genet. Evol. 2016, 40, 331-338. [CrossRef] [PubMed]

42. Chaves, G.M.; Diniz, M.G.; da Silva-Rocha, W.P.; de Souza, L.B.F.C.; Gondim, L.A.M.; Ferreira, M.A.F.; Svidzinski, T.I.E.; Milan, E.P. Species Distribution and Virulence Factors of Candida spp. Isolated from the Oral Cavity of Kidney Transplant Recipients in Brazil. Mycopathologia 2013, 175, 255-263. [CrossRef] [PubMed]

43. Polke, M.; Hube, B.; Jacobsen, I.D. Candida Survival Strategies. Adv. Appl. Microbiol. 2015, 91, 139-235. [CrossRef]

44. Tiraboschi, I.N.; Pozzi, N.C.; Farías, L.; García, S.; Fernández, N.B. Epidemiología, Especies, Resistencia Antifúngica y Evolución de Las Candidemias En Un Hospital Universitario de Buenos Aires, Argentina, Durante 16 Años. Rev. Chil. Infectol. 2017, 34, 431-440. [CrossRef]

45. Fernández-Ruiz, M.; Cardozo, C.; Salavert, M.; Aguilar-Guisado, M.; Escolà-Vergé, L.; Muñoz, P.; Gioia, F.; Montejo, M.; Merino, P.; Cuervo, G.; et al. Candidemia in Solid Organ Transplant Recipients in Spain: Epidemiological Trends and Determinants of Outcome. Transpl. Infect. Dis. 2019, 21, e13195. [CrossRef] [PubMed]

46. Anderson, H.W. Yeast-Like Fungi of the Human Intestinal Tract. J. Infect. Dis. 1917, 21, 341-386. [CrossRef]

47. Plaut, A. Human Infection with Cryptococcus glabratus: Report of Case Involving Uterus and Fallopian Tube. Am. J. Clin. Pathol. 1950, 20, 377-380. [CrossRef]

48. Hazen, K.C. New and Emerging Yeast Pathogens. Clin. Microbiol. Rev. 1995, 8, 462-478. [CrossRef]

49. Rodrigues, C.F.; Silva, S.; Henriques, M. Candida glabrata: A Review of Its Features and Resistance. Eur. J. Clin. Microbiol. Infect. Dis. 2014, 33, 673-688. [CrossRef] 
50. Gabaldón, T.; Fairhead, C. Genomes Shed Light on the Secret Life of Candida glabrata: Not so Asexual, Not so Commensal. Curr. Genet. 2019, 65, 93-98. [CrossRef] [PubMed]

51. Savastano, C.; de Oliveira Silva, E.; Gonçalves, L.L.; Nery, J.M.; Silva, N.C.; Dias, A.L.T. Candida glabrata among Candida spp. from Environmental Health Practitioners of a Brazilian Hospital. Braz. J. Microbiol. 2016, 47, 367-372. [CrossRef]

52. Sakita, K.M.; Faria, D.R.; da Silva, E.M.; Tobaldini-Valério, F.K.; Kioshima, E.S.; Svidzinski, T.I.; de Souza Bonfim-Mendonça, P. Healthcare Workers' Hands as a Vehicle for the Transmission of Virulent Strains of Candida spp.: A Virulence Factor Approach. Microb. Pathog. 2017, 113, 225-232. [CrossRef] [PubMed]

53. de Paula Menezes, R.; Silva, F.F.; Melo, S.G.; Alves, P.G.; Brito, M.O.; de Souza Bessa, M.A.; Amante Penatti, M.P.; Pedroso, R.S.; Abdallah, V.O.; Röder, D.V. Characterization of Candida Species Isolated from the Hands of the Healthcare Workers in the Neonatal Intensive Care Unit. Med. Mycol. 2019, 57, 588-594. [CrossRef] [PubMed]

54. Opulente, D.A.; Langdon, Q.K.; Buh, K.V.; Haase, M.A.B.; Sylvester, K.; Moriarty, R.V.; Jarzyna, M.; Considine, S.L.; Schneider, R.M.; Hittinger, C.T. Pathogenic Budding Yeasts Isolated Outside of Clinical Settings. FEMS Yeast Res. 2019, 19, foz032. [CrossRef]

55. Turner, S.A.; Butler, G. The Candida Pathogenic Species Complex. Cold Spring Harb. Perspect. Med. 2014, 4, a019778. [CrossRef]

56. Swoboda-Kopeć, E.; Sikora, M.; Golas, M.; Piskorska, K.; Gozdowski, D.; Netsvyetayeva, I. Candida nivariensis in Comparison to Different Phenotypes of Candida glabrata. Mycoses 2014, 57, 747-753. [CrossRef]

57. Sikora, M.; Kuthan, R.; Piskorska-Malolepsza, K.; Golas-Pradzynska, M.; Domański, D.; Augustynowicz-Kopeć, E.; SwobodaKopec, E. Prevalence and Antifungal Susceptibility of the Emerging Fungal Species, Candida nivariensis, Isolated in a Teaching Hospital in Poland. Pol. J. Microbiol. 2019, 68, 303-308. [CrossRef]

58. Małek, M.; Mrowiec, P.; Klesiewicz, K.; Skiba-Kurek, I.; Szczepański, A.; Białecka, J.; Żak, I.; Bogusz, B.; Kędzierska, J.; Budak, A.; et al. Prevalence of Human Pathogens of the Clade Nakaseomyces in a Culture Collection-The First Report on Candida bracarensis in Poland. Folia Microbiol. 2019, 64, 307-312. [CrossRef]

59. Correia, A. Candida bracarensis sp. Nov., a Novel Anamorphic Yeast Species Phenotypically Similar to Candida glabrata. Int. J. Syst. Evol. Microbiol. 2006, 56, 313-317. [CrossRef] [PubMed]

60. Alcoba-Flórez, J.; Méndez-Álvarez, S.; Cano, J.; Guarro, J.; Pérez-Roth, E.; del Pilar Arévalo, M. Phenotypic and Molecular Characterization of Candida nivariensis sp. Nov., a Possible New Opportunistic Fungus. J. Clin. Microbiol. 2005, 43, 4107-4111. [CrossRef]

61. Borman, A.M.; Petch, R.; Linton, C.J.; Palmer, M.D.; Bridge, P.D.; Johnson, E.M. Candida nivariensis, an Emerging Pathogenic Fungus with Multidrug Resistance to Antifungal Agents. J. Clin. Microbiol. 2008, 46, 933-938. [CrossRef] [PubMed]

62. Hernando-Ortiz, A.; Mateo, E.; Ortega-Riveros, M.; De-la-Pinta, I.; Quindós, G.; Eraso, E. Caenorhabditis elegans as a Model System To Assess Candida glabrata, Candida nivariensis, and Candida bracarensis Virulence and Antifungal Efficacy. Antimicrob. Agents Chemother. 2020, 64, e00824-20. [CrossRef] [PubMed]

63. Treviño-Rangel, R.D.; Espinosa-Pérez, J.F.; Villanueva-Lozano, H.; Montoya, A.M.; Andrade, A.; Bonifaz, A.; González, G.M. First Report of Candida bracarensis in Mexico: Hydrolytic Enzymes and Antifungal Susceptibility Pattern. Folia Microbiol. 2018, 63, 517-523. [CrossRef] [PubMed]

64. Shi, Y.; Zhu, Y.; Fan, S.; Vitagliano, A.; Liu, X.; Liao, Y.; Liang, Y.; Vitale, S.G. Clinical Characteristics and Antifungal Susceptibility of Candida nivariensis from Vulvovaginal Candidiasis. Gynecol. Obstet. Investig. 2020, 85, 88-93. [CrossRef]

65. Silva, S.; Negri, M.; Henriques, M.; Oliveira, R.; Williams, D.W.; Azeredo, J. Adherence and Biofilm Formation of Non-Candida albicans Candida Species. Trends Microbiol. 2011, 19, 241-247. [CrossRef]

66. Rodrigues, C.F.; Silva, S.; Azeredo, J.; Henriques, M. Candida glabrata's Recurrent Infections: Biofilm Formation during Amphotericin B Treatment. Lett. Appl. Microbiol. 2016, 63, 77-81. [CrossRef]

67. Nakamura-Vasconcelos, S.S.; Fiorini, A.; Zanni, P.D.; de Souza Bonfim-Mendonça, P.; Godoy, J.R.; Almeida-Apolonio, A.A.; Consolaro, M.E.; Svidzinski, T.I. Emergence of Candida glabrata in Vulvovaginal Candidiasis Should Be Attributed to Selective Pressure or Virulence Ability? Arch. Gynecol. Obstet. 2017, 296, 519-526. [CrossRef] [PubMed]

68. Ko, J.-H.; Jung, D.S.; Lee, J.Y.; Kim, H.A.; Ryu, S.Y.; Jung, S.-I.; Joo, E.-J.; Cheon, S.; Kim, Y.-S.; Kim, S.-W.; et al. Changing Epidemiology of Non-albicans Candidemia in Korea. J. Infect. Chemother. 2019, 25, 388-391. [CrossRef]

69. Wang, H.; Xu, Y.-C.; Hsueh, P.-R. Epidemiology of Candidemia and Antifungal Susceptibility in Invasive Candida Species in the Asia-Pacific Region. Future Microbiol. 2016, 11, 1461-1477. [CrossRef]

70. Pote, S.T.; Sonawane, M.S.; Rahi, P.; Shah, S.R.; Shouche, Y.S.; Patole, M.S.; Thakar, M.R.; Sharma, R. Distribution of Pathogenic Yeasts in Different Clinical Samples: Their Identification, Antifungal Susceptibility Pattern, and Cell Invasion Assays. Infect. Drug Resist. 2020, 13, 1133-1145. [CrossRef]

71. Kaan, Ö.; Koç, A.N.; Atalay, M.A.; Mutlu Sarigüzel, F. Molecular Epidemiology, Antifungal Susceptibility and Virulence Factors of Candida glabrata Complex Strains in Kayseri/Turkey. Microb. Pathog. 2021, 154, 104870. [CrossRef]

72. Alves, R.; Barata-Antunes, C.; Casal, M.; Brown, A.J.P.; Van Dijck, P.; Paiva, S. Adapting to Survive: How Candida Overcomes Host-Imposed Constraints during Human Colonization. PLoS Pathog. 2020, 16, e1008478. [CrossRef] [PubMed]

73. Seider, K.; Gerwien, F.; Kasper, L.; Allert, S.; Brunke, S.; Jablonowski, N.; Schwarzmüller, T.; Barz, D.; Rupp, S.; Kuchler, K.; et al. Immune Evasion, Stress Resistance, and Efficient Nutrient Acquisition Are Crucial for Intracellular Survival of Candida glabrata within Macrophages. Eukaryot. Cell 2014, 13, 170-183. [CrossRef] [PubMed]

74. Pais, P.; Galocha, M.; Teixeira, M.C. Genome-Wide Response to Drugs and Stress in the Pathogenic Yeast Candida glabrata. Prog. Mol. Subcell. Biol. 2019, 58, 155-193. [CrossRef] 
75. West, L.; Lowman, D.W.; Mora-Montes, H.M.; Grubb, S.; Murdoch, C.; Thornhill, M.H.; Gow, N.A.R.; Williams, D.; Haynes, K. Differential Virulence of Candida glabrata Glycosylation Mutants. J. Biol. Chem. 2013, 288, 22006-22018. [CrossRef] [PubMed]

76. Briones-Martin-Del-Campo, M.; Orta-Zavalza, E.; Juarez-Cepeda, J.; Gutierrez-Escobedo, G.; Cañas-Villamar, I.; Castaño, I.; De Las Peñas, A. The Oxidative Stress Response of the Opportunistic Fungal Pathogen Candida glabrata. Rev. Iberoam. Micol. 2014, 31, 67-71. [CrossRef]

77. Riedelberger, M.; Penninger, P.; Tscherner, M.; Hadriga, B.; Brunnhofer, C.; Jenull, S.; Stoiber, A.; Bourgeois, C.; Petryshyn, A.; Glaser, W.; et al. Type I Interferons Ameliorate Zinc Intoxication of Candida glabrata by Macrophages and Promote Fungal Immune Evasion. iScience 2020, 23, 101121. [CrossRef]

78. Angoulvant, A.; Guitard, J.; Hennequin, C. Old and New Pathogenic Nakaseomyces Species: Epidemiology, Biology, Identification, Pathogenicity and Antifungal Resistance. FEMS Yeast Res. 2015, 16, fov114. [CrossRef]

79. Köhler, J.R.; Acosta-Zaldívar, M.; Qi, W. Phosphate in Virulence of Candida albicans and Candida glabrata. J. Fungi 2020, 6, 40. [CrossRef]

80. Gutiérrez-Escobedo, G.; Hernández-Carreón, O.; Morales-Rojano, B.; Revuelta-Rodríguez, B.; Vázquez-Franco, N.; Castaño, I.; De Las Peñas, A. Candida glabrata Peroxiredoxins, Tsa1 and Tsa2, and Sulfiredoxin, Srx1, Protect against Oxidative Damage and Are Necessary for Virulence. Fungal Genet. Biol. 2020, 135, 103287. [CrossRef]

81. Martínez-Pastor, M.T.; Puig, S. Adaptation to Iron Deficiency in Human Pathogenic Fungi. Biochim. Biophys. Acta Mol. Cell Res. 2020, 1867, 118797. [CrossRef] [PubMed]

82. Seider, K.; Brunke, S.; Schild, L.; Jablonowski, N.; Wilson, D.; Majer, O.; Barz, D.; Haas, A.; Kuchler, K.; Schaller, M.; et al. The Facultative Intracellular Pathogen Candida glabrata Subverts Macrophage Cytokine Production and Phagolysosome Maturation. J. Immunol. 2011, 187, 3072-3086. [CrossRef] [PubMed]

83. Nobile, C.J.; Fox, E.P.; Nett, J.E.; Sorrells, T.R.; Mitrovich, Q.M.; Hernday, A.D.; Tuch, B.B.; Andes, D.R.; Johnson, A.D. A Recently Evolved Transcriptional Network Controls Biofilm Development in Candida albicans. Cell 2012, 148, 126-138. [CrossRef]

84. Beyer, R.; Jandric, Z.; Zutz, C.; Gregori, C.; Willinger, B.; Jacobsen, I.D.; Kovarik, P.; Strauss, J.; Schüller, C. Competition of Candida glabrata against Lactobacillus Is Hog1 Dependent. Cell. Microbiol. 2018, 20, e12943. [CrossRef]

85. De Las Peñas, A.; Juárez-Cepeda, J.; López-Fuentes, E.; Briones-Martín-del-Campo, M.; Gutiérrez-Escobedo, G.; Castaño, I. Local and Regional Chromatin Silencing in Candida glabrata: Consequences for Adhesion and the Response to Stress. FEMS Yeast Res. 2015, 15, fov056. [CrossRef]

86. Rai, M.N.; Sharma, V.; Balusu, S.; Kaur, R. An Essential Role for Phosphatidylinositol 3-Kinase in the Inhibition of Phagosomal Maturation, Intracellular Survival and Virulence in Candida glabrata. Cell. Microbiol. 2015, 17, 269-287. [CrossRef] [PubMed]

87. Pappas, P.G.; Lionakis, M.S.; Arendrup, M.C.; Ostrosky-Zeichner, L.; Kullberg, B.J. Invasive Candidiasis. Nat. Rev. Dis. Primers 2018, 4, 18026. [CrossRef]

88. Riedelberger, M.; Penninger, P.; Tscherner, M.; Seifert, M.; Jenull, S.; Brunnhofer, C.; Scheidl, B.; Tsymala, I.; Bourgeois, C.; Petryshyn, A.; et al. Type I Interferon Response Dysregulates Host Iron Homeostasis and Enhances Candida glabrata Infection. Cell Host Microbe 2020, 27, 454-466.e8. [CrossRef]

89. Rasheed, M.; Battu, A.; Kaur, R. Aspartyl Proteases in Candida glabrata are Required for Suppression of the Host Innate Immune Response. J. Biol. Chem. 2018, 293, 6410-6433. [CrossRef]

90. Gabaldón, T.; Gómez-Molero, E.; Bader, O. Molecular Typing of Candida glabrata. Mycopathologia 2020, 185, 755-764. [CrossRef]

91. He, C.; Song, Y.; Chang, X.K. Pathogenicity and drug-resistance analysis of Candida glabrata in patients with oral candidiasis. Zhonghua Yi Xue Za Zhi 2020, 100, 1778-1782. [CrossRef]

92. Cai, S.; Xu, J.; Shao, Y.; Gong, J.; Zhao, F.; He, L.; Shan, X. Rapid Identification of the Candida glabrata Species Complex by High-Resolution Melting Curve Analysis. J. Clin. Lab. Anal. 2020, 34, e23226. [CrossRef] [PubMed]

93. Smyth, J.; Mullen, C.C.; Jack, L.; Collier, A.; Bal, A.M. Diabetes, Malignancy and Age as Predictors of Candida glabrata Bloodstream Infection: A Re-Evaluation of the Risk Factors. J. Mycol. Med. 2018, 28, 547-550. [CrossRef]

94. Rosenwald, A.G.; Arora, G.; Ferrandino, R.; Gerace, E.L.; Mohammednetej, M.; Nosair, W.; Rattila, S.; Subic, A.Z.; Rolfes, R. Identification of Genes in Candida glabrata Conferring Altered Responses to Caspofungin, a Cell Wall Synthesis Inhibitor. G3 Genes Genomes Genet. 2016, 6, 2893-2907. [CrossRef]

95. Subramanya, S.H.; Baral, B.P.; Sharan, N.K.; Nayak, N.; Metok, Y.; Sathian, B.; Bairy, I.; Gokhale, S. Antifungal Susceptibility and Phenotypic Virulence Markers of Candida Species Isolated from Nepal. BMC Res. Notes 2017, 10, 543. [CrossRef] [PubMed]

96. Márquez, F.; Iturrieta, I.; Calvo, M.; Urrutia, M.; Godoy-Martínez, P. Epidemiología y Susceptibilidad Antifúngica de Especies Causantes de Candidemia En La Ciudad de Valdivia, Chile. Rev. Chil. Infectol. 2017, 34, 441-446. [CrossRef] [PubMed]

97. Rasheed, M.; Battu, A.; Kaur, R. Host-Pathogen Interaction in Candida glabrata Infection: Current Knowledge and Implications for Antifungal Therapy. Expert Rev. Anti-Infect. Ther. 2020, 18, 1093-1103. [CrossRef]

98. Borman, A.M.; Muller, J.; Walsh-Quantick, J.; Szekely, A.; Patterson, Z.; Palmer, M.D.; Fraser, M.; Johnson, E.M. Fluconazole Resistance in Isolates of Uncommon Pathogenic Yeast Species from the United Kingdom. Antimicrob. Agents Chemother. 2019, 63, e00211-19. [CrossRef] [PubMed]

99. Mashaly, G.; Shrief, R. Candida glabrata Complex from Patients with Healthcare-Associated Infections in Mansoura University Hospitals, Egypt: Distribution, Antifungal Susceptibility and Effect of Fluconazole and Polymyxin B Combination. Germs 2019, 9, 125-132. [CrossRef] 
100. Miranda-Cadena, K.; Marcos-Arias, C.; Mateo, E.; Aguirre, J.M.; Quindós, G.; Eraso, E. Prevalence and Antifungal Susceptibility Profiles of Candida glabrata, Candida parapsilosis and Their Close-Related Species in Oral Candidiasis. Arch. Oral Biol. 2018, 95, 100-107. [CrossRef] [PubMed]

101. Marín Martínez, E.M.; Aller García, A.I.; Martín-Mazuelos, E. Epidemiology, risk factors and in vitro susceptibility in candidaemia due to non-Candida albicans species. Rev. Iberoam. Micol. 2016, 33, 248-252. [CrossRef] [PubMed]

102. Healey, K.R.; Jimenez Ortigosa, C.; Shor, E.; Perlin, D.S. Genetic Drivers of Multidrug Resistance in Candida glabrata. Front. Microbiol. 2016, 7, 1995. [CrossRef] [PubMed]

103. Li, D.; Xia, R.; Zhang, Q.; Bai, C.; Li, Z.; Zhang, P. Evaluation of Candidemia in Epidemiology and Risk Factors among Cancer Patients in a Cancer Center of China: An 8-Year Case-Control Study. BMC Infect. Dis. 2017, 17, 536. [CrossRef] [PubMed]

104. Ngouana, T.K.; Toghueo, R.M.K.; Kenfack, I.F.; Lachaud, L.; Nana, A.K.; Tadjou, L.; Kouanfack, C.; Boyom, F.F.; Bertout, S. Epidemiology and Antifungal Susceptibility Testing of Non-albicans Candida Species Colonizing Mucosae of HIV-Infected Patients in Yaoundé (Cameroon). J. Mycol. Med. 2019, 29, 233-238. [CrossRef]

105. Waikhom, S.D.; Afeke, I.; Kwawu, G.S.; Mbroh, H.K.; Osei, G.Y.; Louis, B.; Deku, J.G.; Kasu, E.S.; Mensah, P.; Agede, C.Y.; et al. Prevalence of Vulvovaginal Candidiasis among Pregnant Women in the Ho Municipality, Ghana: Species Identification and Antifungal Susceptibility of Candida Isolates. BMC Pregnancy Childbirth 2020, 20, 266. [CrossRef]

106. Arastehfar, A.; Daneshnia, F.; Salehi, M.-R.; Zarrinfar, H.; Khodavaisy, S.; Haas, P.-J.; Roudbary, M.; Najafzadeh, M.-J.; Zomorodian, K.; Charsizadeh, A.; et al. Molecular Characterization and Antifungal Susceptibility Testing of Candida nivariensis from Blood Samples-An Iranian Multicentre Study and a Review of the Literature. J. Med. Microbiol. 2019, 68, 770-777. [CrossRef]

107. Alobaid, K.; Khan, Z. Epidemiologic Characteristics of Adult Candidemic Patients in a Secondary Hospital in Kuwait: A Retrospective Study. J. Mycol. Med. 2019, 29, 35-38. [CrossRef]

108. Al-Baqsami, Z.F.; Ahmad, S.; Khan, Z. Antifungal Drug Susceptibility, Molecular Basis of Resistance to Echinocandins and Molecular Epidemiology of Fluconazole Resistance among Clinical Candida glabrata Isolates in Kuwait. Sci. Rep. 2020, 10, 6238. [CrossRef]

109. Gülmez, D.; Alp, S.; Gursoy, G.; Ayaz, C.M.; Dogan, O.; Arikan-Akdagli, S.; Akova, M. Mixed Fungaemia: An 18-Year Report from a Tertiary-Care University Hospital and a Systematic Review. Clin. Microbiol. Infect. 2020, 26, 833-841. [CrossRef]

110. Aldejohann, A.M.; Herz, M.; Martin, R.; Walther, G.; Kurzai, O. Emergence of Resistant Candida glabrata in Germany. JAC Antimicrob. Resist. 2021, 3, dlab122. [CrossRef]

111. Coste, A.T.; Kritikos, A.; Li, J.; Khanna, N.; Goldenberger, D.; Garzoni, C.; Zehnder, C.; Boggian, K.; Neofytos, D.; Riat, A.; et al. Emerging Echinocandin-Resistant Candida albicans and glabrata in Switzerland. Infection 2020, 48, 761-766. [CrossRef] [PubMed]

112. Fraser, M.; Borman, A.M.; Thorn, R.; Lawrance, L.M. Resistance to Echinocandin Antifungal Agents in the United Kingdom in Clinical Isolates of Candida glabrata: Fifteen Years of Interpretation and Assessment. Med. Mycol. 2020, 58, 219-226. [CrossRef]

113. Szweda, P.; Gucwa, K.; Romanowska, E.; Dzierz Anowska-Fangrat, K.; Naumiuk, Ł.; Brillowska-Da Browska, A.; WojciechowskaKoszko, I.; Milewski, S. Mechanisms of Azole Resistance among Clinical Isolates of Candida glabrata in Poland. J. Med. Microbiol. 2015, 64, 610-619. [CrossRef] [PubMed]

114. Medina, N.; Soto-Debrán, J.C.; Seidel, D.; Akyar, I.; Badali, H.; Barac, A.; Bretagne, S.; Cag, Y.; Cassagne, C.; Castro, C.; et al. MixInYeast: A multicenter study on mixed yeast infections. J. Fungi 2021, 7, 13. [CrossRef]

115. Hull, C.M.; Parker, J.E.; Bader, O.; Weig, M.; Gross, U.; Warrilow, A.G.S.; Kelly, D.E.; Kelly, S.L. Facultative Sterol Uptake in an Ergosterol-Deficient Clinical Isolate of Candida glabrata Harboring a Missense Mutation in ERG11 and Exhibiting Cross-Resistance to Azoles and Amphotericin B. Antimicrob. Agents Chemother. 2012, 56, 4223-4232. [CrossRef] [PubMed]

116. Colombo, A.L.; Júnior, J.N.; Guinea, J. Emerging Multidrug-Resistant Candida Species. Curr. Opin. Infect. Dis. 2017, 30, 528-538. [CrossRef]

117. Montagna, M.T.; Lovero, G.; Coretti, C.; Martinelli, D.; De Giglio, O.; Iatta, R.; Balbino, S.; Rosato, A.; Caggiano, G. Susceptibility to Echinocandins of Candida spp. Strains Isolated in Italy Assessed by European Committee for Antimicrobial Susceptibility Testing and Clinical Laboratory Standards Institute Broth Microdilution Methods. BMC Microbiol. 2015, 15, 106. [CrossRef] [PubMed]

118. Vale-Silva, L.; Beaudoing, E.; Tran, V.D.T.; Sanglard, D. Comparative Genomics of Two Sequential Candida glabrata Clinical Isolates. G3 Genes Genomes Genet. 2017, 7, 2413-2426. [CrossRef] [PubMed]

119. Simonicova, L.; Moye-Rowley, W.S. Functional Information from Clinically-Derived Drug Resistant Forms of the Candida glabrata Pdr1 Transcription Factor. PLoS Genet. 2020, 16, e1009005. [CrossRef]

120. López-Soria, L.M.; Bereciartua, E.; Santamaría, M.; Soria, L.M.; Hernández-Almaraz, J.L.; Mularoni, A.; Nieto, J.; Montejo, M. First case report of catheter-related fungemia by Candida nivariensis in the Iberian Peninsula. Rev. Iberoam. Micol. 2013, $30,69-71$. [CrossRef] [PubMed]

121. Coste, A.; Selmecki, A.; Forche, A.; Diogo, D.; Bougnoux, M.-E.; d’Enfert, C.; Berman, J.; Sanglard, D. Genotypic evolution of azole resistance mechanisms in sequential Candida albicans isolates. Eukaryot. Cell 2007, 6, 1889-1904. [CrossRef]

122. Morio, F.; Pagniez, F.; Besse, M.; Gay-andrieu, F.; Miegeville, M.; Pape, P.L. Deciphering azole resistance mechanisms with a focus on transcription factor-encoding genes TAC1, MRR1 and UPC2 in a set of fluconazole-resistant clinical isolates of Candida albicans. Int. J. Antimicrob. Agents 2013, 42, 410-415. [CrossRef] 
123. Nagayoshi, Y.; Miyazaki, T.; Shimamura, S.; Nakayama, H.; Minematsu, A.; Yamauchi, S.; Takazono, T.; Nakamura, S.; Yanagihara, K.; Kohno, S.; et al. Unexpected Effects of Azole Transporter Inhibitors on Antifungal Susceptibility in Candida glabrata and Other Pathogenic Candida Species. PLoS ONE 2017, 12, e0180990. [CrossRef]

124. Hou, X.; Xiao, M.; Wang, H.; Yu, S.-Y.; Zhang, G.; Zhao, Y.; Xu, Y.-C. Profiling of PDR1 and MSH2 in Candida glabrata Bloodstream Isolates from a Multicenter Study in China. Antimicrob. Agents Chemother. 2018, 62, e00153-18. [CrossRef]

125. Culakova, H.; Dzugasova, V.; Perzelova, J.; Gbelska, Y.; Subik, J. Mutation of the CgPDR16 Gene Attenuates Azole Tolerance and Biofilm Production in Pathogenic Candida glabrata. Yeast 2013, 30, 403-414. [CrossRef] [PubMed]

126. Farahyar, S.; Zaini, F.; Kordbacheh, P.; Rezaie, S.; Falahati, M.; Safara, M.; Raoofian, R.; Hatami, K.; Mohebbi, M.; Heidari, M. Expression of Efflux Pumps and Fatty Acid Activator One Genes in Azole Resistant Candida glabrata Isolated from Immunocompromised Patients. Acta Med. Iran. 2016, 54, 458-464.

127. Yu, S.-J.; Chang, Y.-L.; Chen, Y.-L. Deletion of ADA2 Increases Antifungal Drug Susceptibility and Virulence in Candida glabrata. Antimicrob. Agents Chemother. 2018, 62, e01924-17. [CrossRef] [PubMed]

128. Pristov, K.E.; Ghannoum, M.A. Resistance of Candida to azoles and echinocandins worldwide. Clin. Microbiol. Infect. 2019, 25, 792-798. [CrossRef] [PubMed]

129. Alexander, B.D.; Johnson, M.D.; Pfeiffer, C.D.; Jiménez-Ortigosa, C.; Catania, J.; Booker, R.; Castanheira, M.; Messer, S.A.; Perlin, D.S.; Pfaller, M.A. Increasing Echinocandin Resistance in Candida glabrata: Clinical Failure Correlates with Presence of FKS Mutations and Elevated Minimum Inhibitory Concentrations. Clin. Infect. Dis. 2013, 56, 1724-1732. [CrossRef] [PubMed]

130. Duxbury, S.J.N.; Bates, S.; Beardmore, R.E.; Gudelj, I. Evolution of Drug-Resistant and Virulent Small Colonies in Phenotypically Diverse Populations of the Human Fungal Pathogen Candida glabrata. Proc. Biol. Sci. 2020, 287, 761. [CrossRef]

131. Bordallo-Cardona, M.Á.; Marcos-Zambrano, L.J.; Sánchez-Carrillo, C.; de la Pedrosa, E.G.G.; Cantón, R.; Bouza, E.; Escribano, P.; Guinea, J. Mutant Prevention Concentration and Mutant Selection Window of Micafungin and Anidulafungin in Clinical Candida glabrata Isolates. Antimicrob. Agents Chemother. 2018, 62, e01982-17. [CrossRef]

132. Espinel-Ingroff, A.; Arendrup, M.; Cantón, E.; Cordoba, S.; Dannaoui, E.; García-Rodríguez, J.; Gonzalez, G.M.; Govender, N.P.; Martin-Mazuelos, E.; Lackner, M.; et al. Multicenter Study of Method-Dependent Epidemiological Cutoff Values for Detection of Resistance in Candida spp. and Aspergillus spp. to Amphotericin B and Echinocandins for the Etest Agar Diffusion Method. Antimicrob. Agents Chemother. 2017, 61, e01792-16. [CrossRef] [PubMed]

133. Katiyar, S.K.; Alastruey-Izquierdo, A.; Healey, K.R.; Johnson, M.E.; Perlin, D.S.; Edlind, T.D. Fks1 and Fks2 Are Functionally Redundant but Differentially Regulated in Candida glabrata: Implications for Echinocandin Resistance. Antimicrob. Agents Chemother. 2012, 56, 6304-6309. [CrossRef]

134. Vandeputte, P.; Tronchin, G.; Larcher, G.; Ernoult, E.; Bergès, T.; Chabasse, D.; Bouchara, J.P. A nonsense mutation in the ERG6 gene leads to reduced susceptibility to polyenes in a clinical isolate of Candida glabrata. Antimicrob. Agents Chemother. 2008, 52, 3701-3709. [CrossRef] [PubMed]

135. Minematsu, A.; Miyazaki, T.; Shimamura, S.; Nishikawa, H.; Nakayama, H.; Takazono, T.; Saijo, T.; Yamamoto, K.; Imamura, Y.; Yanagihara, K.; et al. Vacuolar Proton-Translocating ATPase Is Required for Antifungal Resistance and Virulence of Candida glabrata. PLoS ONE 2019, 14, e0210883. [CrossRef]

136. Roetzer, A.; Gregori, C.; Jennings, A.M.; Quintin, J.; Ferrandon, D.; Butler, G.; Kuchler, K.; Ammerer, G.; Schüller, C. Candida glabrata Environmental Stress Response Involves Saccharomyces cerevisiae Msn2/4 Orthologous Transcription Factors. Mol. Microbiol. 2008, 69, 603-620. [CrossRef] [PubMed]

137. Fujita, S.; Senda, Y.; Okusi, T.; Ota, Y.; Takada, H.; Yamada, K.; Kawano, M. Catheter-related fungemia due to fluconazole-resistant Candida nivariensis. J. Clin. Microbiol. 2007, 45, 3459-3461. [CrossRef] [PubMed]

138. Kaur, R.; Ma, B.; Cormack, B.P. A family of glycosylphosphatidylinositol-linked aspartyl proteases is required for virulence of Candida glabrata. Proc. Natl. Acad. Sci. USA 2007, 104, 7628-7633. [CrossRef]

139. Sikora, M.; Dabkowska, M.; Swoboda-Kopec, E.; Jarzynka, S.; Netsvyetayeva, I.; Jaworska-Zaremba, M.; Pertkiewicz, M.; Mlynarczyk, G. Differences in Proteolytic Activity and Gene Profiles of Fungal Strains Isolated from the Total Parenteral Nutrition Patients. Folia Microbiol. 2011, 56, 143-148. [CrossRef]

140. Cuenca-Estrella, M.; Gomez-Lopez, A.; Isla, G.; Rodriguez, D.; Almirante, B.; Pahissa, A.; Rodriguez-Tudela, J.L. Barcelona Candidemia Project Study Group Prevalence of Candida bracarensis and Candida nivariensis in a Spanish Collection of Yeasts: Comparison of Results from a Reference Centre and from a Population-Based Surveillance Study of Candidemia. Med. Mycol. 2011, 49, 525-529. [CrossRef]

141. Galocha, M.; Pais, P.; Cavalheiro, M.; Pereira, D.; Viana, R.; Teixeira, M.C. Divergent Approaches to Virulence in C. albicans and C. glabrata: Two Sides of the Same Coin. Int. J. Mol. Sci. 2019, 20, 2345. [CrossRef]

142. de Melo Riceto, É.B.; de Paula Menezes, R.; Penatti, M.P.; dos Santos Pedroso, R. Enzymatic and Hemolytic Activity in Different Candida Species. Rev. Iberoam. Micol. 2015, 32, 79-82. [CrossRef]

143. Mohandas, V.; Ballal, M. Distribution of Candida Species in Different Clinical Samples and Their Virulence: Biofilm Formation, Proteinase and Phospholipase Production: A Study on Hospitalized Patients in Southern India. J. Glob. Infect. Dis. $2011,3,4$. [CrossRef] [PubMed]

144. Dabiri, S.; Shams-Ghahfarokhi, M.; Razzaghi-Abyaneh, M. Comparative Analysis of Proteinase, Phospholipase, Hydrophobicity and Biofilm Forming Ability in Candida Species Isolated from Clinical Specimens. J. Mycol. Med. 2018, 28, 437-442. [CrossRef] 
145. Kalaiarasan, K.; Singh, R.; Chaturvedula, L. Changing Virulence Factors among Vaginal Non-albicans Candida Species. Indian J. Med. Microbiol. 2018, 36, 364-368. [CrossRef]

146. Silva, S.; Negri, M.; Henriques, M.; Oliveira, R.; Williams, D.W.; Azeredo, J. Candida glabrata, Candida parapsilosis and Candida tropicalis: Biology, Epidemiology, Pathogenicity and Antifungal Resistance. FEMS Microbiol. Rev. 2012, 36, 288-305. [CrossRef] [PubMed]

147. Berila, N.; Hyroššová, P.; Šubík, J. Oxidative Stress Response and Virulence Factors in Candida glabrata Clinical Isolates. Folia Microbiol. 2011, 56, 116-121. [CrossRef] [PubMed]

148. Atalay, M.A.; Koc, A.N.; Demir, G.; Sav, H. Investigation of Possible Virulence Factors in Candida Strains Isolated from Blood Cultures. Niger. J. Clin. Pract. 2015, 18, 52-55. [CrossRef] [PubMed]

149. Alves, R.; Kastora, S.L.; Gomes-Gonçalves, A.; Azevedo, N.; Rodrigues, C.F.; Silva, S.; Demuyser, L.; Van Dijck, P.; Casal, M.; Brown, A.J.P.; et al. Transcriptional Responses of Candida glabrata Biofilm Cells to Fluconazole Are Modulated by the Carbon Source. npj Biofilms Microbiomes 2020, 6, 4. [CrossRef]

150. Tam, P.; Gee, K.; Piechocinski, M.; Macreadie, I. Candida glabrata, Friend and Foe. J. Fungi 2015, 1, 277-292. [CrossRef]

151. Kalkanci, A.; GüZel, A.B.; Khalil, I.I.J.; Aydin, M.; Ilkit, M.; Kuştimur, S. Yeast Vaginitis during Pregnancy: Susceptibility Testing of 13 Antifungal Drugs and Boric Acid and the Detection of Four Virulence Factors. Med. Mycol. 2012, 50, 585-593. [CrossRef]

152. Alves, C.T.; Wei, X.-Q.; Silva, S.; Azeredo, J.; Henriques, M.; Williams, D.W. Candida albicans Promotes Invasion and Colonisation of Candida glabrata in a Reconstituted Human Vaginal Epithelium. J. Infect. 2014, 69, 396-407. [CrossRef]

153. Valotteau, C.; Prystopiuk, V.; Cormack, B.P.; Dufrêne, Y.F. Atomic Force Microscopy Demonstrates That Candida glabrata Uses Three Epa Proteins To Mediate Adhesion to Abiotic Surfaces. mSphere 2019, 4, e00277-19. [CrossRef]

154. Brunke, S.; Hube, B. Two Unlike Cousins: Candida albicans and C. glabrata Infection Strategies. Cell. Microbiol. 2013, 15, 701-708. [CrossRef] [PubMed]

155. Pärnänen, P.; Meurman, J.H.; Nikula-Ijäs, P. A Novel Candida glabrata Cell Wall Associated Serine Protease. Biochem. Biophys. Res. Commun. 2015, 457, 676-680. [CrossRef]

156. Juárez-Cepeda, J.; Orta-Zavalza, E.; Cañas-Villamar, I.; Arreola-Gómez, J.; Pérez-Cornejo, G.P.; Hernández-Carballo, C.Y.; Gutiérrez-Escobedo, G.; Castaño, I.; De Las Peñas, A. The EPA2 Adhesin Encoding Gene Is Responsive to Oxidative Stress in the Opportunistic Fungal Pathogen Candida glabrata. Curr. Genet. 2015, 61, 529-544. [CrossRef]

157. Rodrigues, C.; Rodrigues, M.; Silva, S.; Henriques, M. Candida glabrata Biofilms: How Far Have We Come? J. Fungi $2017,3,11$. [CrossRef] [PubMed]

158. López-Fuentes, E.; Gutiérrez-Escobedo, G.; Timmermans, B.; Van Dijck, P.; De Las Peñas, A.; Castaño, I. Candida glabrata's Genome Plasticity Confers a Unique Pattern of Expressed Cell Wall Proteins. J. Fungi 2018, 4, 67. [CrossRef]

159. Llopis-Torregrosa, V.; Vaz, C.; Monteoliva, L.; Ryman, K.; Engstrom, Y.; Gacser, A.; Gil, C.; Ljungdahl, P.O.; Sychrová, H. Trk1-Mediated Potassium Uptake Contributes to Cell-Surface Properties and Virulence of Candida glabrata. Sci. Rep. 2019 , 9, 7529. [CrossRef] [PubMed]

160. Gómez-Molero, E.; de Boer, A.D.; Dekker, H.L.; Moreno-Martínez, A.; Kraneveld, E.A.; Ichsan; Chauhan, N.; Weig, M.; de Soet, J.J.; de Koster, C.G.; et al. Proteomic Analysis of Hyperadhesive Candida glabrata Clinical Isolates Reveals a Core Wall Proteome and Differential Incorporation of Adhesins. FEMS Yeast Res. 2015, 15, fov098. [CrossRef] [PubMed]

161. Roetzer, A.; Gabaldón, T.; Schüller, C. From Saccharomyces Cerevisiae to Candida glabrata in a Few Easy Steps: Important Adaptations for an Opportunistic Pathogen. FEMS Microbiol. Lett. 2011, 314, 1-9. [CrossRef] [PubMed]

162. Gabaldón, T.; Martin, T.; Marcet-Houben, M.; Durrens, P.; Bolotin-Fukuhara, M.; Lespinet, O.; Arnaise, S.; Boisnard, S.; Aguileta, G.; Atanasova, R.; et al. Comparative Genomics of Emerging Pathogens in the Candida glabrata Clade. BMC Genom. 2013, 14, 623. [CrossRef]

163. Olson, M.L.; Jayaraman, A.; Kao, K.C. Relative Abundances of Candida albicans and Candida glabrata in in vitro Coculture Biofilms Impact Biofilm Structure and Formation. Appl. Environ. Microbiol. 2018, 84, e02769-17. [CrossRef]

164. Cortés-Acosta, E.; Ibarra, J.A.; Ramírez-Saad, H.; Vargas-Mendoza, C.F.; Villa-Tanaca, L.; Hernández-Rodríguez, C. Polymorphism in the Regulatory Regions of Genes CgYPS1 and CgYPS7 Encoding Yapsins in Candida glabrata Is Associated with Changes in Expression Levels. FEMS Yeast Res. 2017, 17, fox077. [CrossRef]

165. Muñoz-Duarte, A.R.; Castrejón-Jiménez, N.S.; Baltierra-Uribe, S.L.; Pérez-Rangel, S.J.; Carapia-Minero, N.; Castañeda-Sánchez, J.I.; Luna-Herrera, J.; López-Santiago, R.; Rodríguez-Tovar, A.V.; García-Pérez, B.E. Candida glabrata Survives and Replicates in Human Osteoblasts. Pathog. Dis. 2016, 74, ftw030. [CrossRef]

166. López-Fuentes, E.; Hernández-Hernández, G.; Castanedo, L.; Gutiérrez-Escobedo, G.; Oktaba, K.; De las Peñas, A.; Castaño, I. Chromatin Loop Formation Induced by a Subtelomeric Protosilencer Represses EPA Genes in Candida glabrata. Genetics 2018, 210, 113-128. [CrossRef]

167. Desai, C.; Mavrianos, J.; Chauhan, N. Candida glabrata Pwp7p and Aed1p are Required for Adherence to Human Endothelial Cells. FEMS Yeast Res. 2011, 11, 595-601. [CrossRef] [PubMed]

168. Figueiredo-Carvalho, M.H.; Ramos, L.D.; Barbedo, L.S.; Chaves, A.L.; Muramoto, I.A.; Santos, A.L.; Almeida-Paes, R.; ZancopéOliveira, R.M. First Description of Candida nivariensis in Brazil: Antifungal Susceptibility Profile and Potential Virulence Attributes. Mem. Inst. Oswaldo Cruz 2016, 111, 51-58. [CrossRef]

169. Luo, G.; Samaranayake, L.P. Candida glabrata, an emerging fungal pathogen, exhibits superior relative cell surface hydrophobicity and adhesion to denture acrylic surfaces compared with Candida albicans. Apmis 2002, 110, 601-610. [CrossRef] 
170. Negri, M.; Gonçalves, V.; Silva, S.; Henriques, M.; Azeredo, J.; Oliveira, R. Crystal Violet Staining to Quantify Candida Adhesion to Epithelial Cells. Br. J. Biomed. Sci. 2010, 67, 120-125. [CrossRef] [PubMed]

171. Vieira de Melo, A.P.; Zuza-Alves, D.L.; da Silva-Rocha, W.P.; Ferreira Canário de Souza, L.B.; Francisco, E.C.; Salles de Azevedo Melo, A.; Maranhão Chaves, G. Virulence Factors of Candida spp. Obtained from Blood Cultures of Patients with Candidemia Attended at Tertiary Hospitals in Northeast Brazil. J. Mycol. Med. 2019, 29, 132-139. [CrossRef]

172. Mutlu Sariguzel, F.; Berk, E.; Koc, A.N.; Sav, H.; Demir, G. Investigation of the Relationship between Virulence Factors and Genotype of Candida spp. Isolated from Blood Cultures. J. Infect. Dev. Ctries 2015, 9, 857-864. [CrossRef]

173. Moreira, A.; Silva, S.; Botelho, C.; Sampaio, P.; Pais, C.; Henriques, M. Candida bracarensis: Evaluation of Virulence Factors and Its Tolerance to Amphotericin B and Fluconazole. Mycopathologia 2015, 180, 305-315. [CrossRef]

174. Bairwa, G.; Rasheed, M.; Taigwal, R.; Sahoo, R.; Kaur, R. GPI (Glycosylphosphatidylinositol)-Linked Aspartyl Proteases Regulate Vacuole Homoeostasis in Candida glabrata. Biochem. J. 2014, 458, 323-334. [CrossRef] [PubMed]

175. Rapala-Kozik, M.; Bochenska, O.; Zajac, D.; Karkowska-Kuleta, J.; Gogol, M.; Zawrotniak, M.; Kozik, A. Extracellular Proteinases of Candida Species Pathogenic Yeasts. Mol. Oral Microbiol. 2018, 33, 113-124. [CrossRef] [PubMed]

176. Yagmur, G.; Sav, H.; Ziyade, N.; Elgormus, N.; Sen, S.; Akkoyun Bilgi, E.; Atan, Y.; Buyuk, Y.; Kiraz, N. Evaluation of Virulence Factors and Antifungal Susceptibility in Yeast Isolates from Postmortem Specimens. J. Forensic Sci. 2016, 61, 1000-1006. [CrossRef] [PubMed]

177. Rossoni, R.D.; Barbosa, J.O.; Vilela, S.F.G.; dos Santos, J.D.; Jorge, A.O.C.; Junqueira, J.C. Correlation of Phospholipase and Proteinase Production of Candida with in vivo Pathogenicity in Galleria mellonella. Braz. J. Oral Sci. 2013, 12, 199-204. [CrossRef]

178. Hacioglu, M.; Guzel, C.B.; Savage, P.B.; Tan, A.S.B. Antifungal Susceptibilities, in vitro Production of Virulence Factors and Activities of Ceragenins against Candida spp. Isolated from Vulvovaginal Candidiasis. Med. Mycol. 2019, 57, 291-299. [CrossRef]

179. Sriphannam, C.; Nuanmuang, N.; Saengsawang, K.; Amornthipayawong, D.; Kummasook, A. Anti-Fungal Susceptibility and Virulence Factors of Candida spp. Isolated from Blood Cultures. J. Mycol. Med. 2019, 29, 325-330. [CrossRef]

180. Barbosa, A.H.; Damasceno, J.L.; Casemiro, L.A.; Martins, C.H.G.; Pires, R.H.; Candido, R.C. Susceptibility to Oral Antiseptics and Virulence Factors Ex Vivo Associated with Candida spp. Isolated from Dental Prostheses. J. Prosthodont. 2019, 28, 398-408. [CrossRef]

181. Pereira, C.A.; Domingues, N.; Araújo, M.I.D.S.A.; Junqueira, J.C.; Back-Brito, G.N.; Jorge, A.O.C. Production of Virulence Factors in Candida Strains Isolated from Patients with Denture Stomatitis and Control Individuals. Diagn. Microbiol. Infect. Dis. 2016, 85, 66-72. [CrossRef] [PubMed]

182. Tay, S.T.; Lotfalikhani, A.; Sabet, N.S.; Ponnampalavanar, S.; Sulaiman, S.; Na, S.L.; Ng, K.P. Occurrence and Characterization of Candida nivariensis from a Culture Collection of Candida glabrata Clinical Isolates in Malaysia. Mycopathologia 2014, 178, 307-314. [CrossRef] [PubMed]

183. Schaller, M.; Borelli, C.; Korting, H.C.; Hube, B. Hydrolytic enzymes as virulence factors of Candida albicans. Mycoses 2005, 48, 365-367. [CrossRef]

184. Marcos-Arias, C.; Eraso, E.; Madariaga, L.; Aguirre, J.M.; Quindós, G. Phospholipase and Proteinase Activities of Candida Isolates from Denture Wearers. Mycoses 2011, 54, e10-e16. [CrossRef] [PubMed]

185. Kumari, V.; Banerjee, T.; Kumar, P.; Pandey, S.; Tilak, R. Emergence of Non-albicans Candida among Candidal Vulvovaginitis Cases and Study of Their Potential Virulence Factors, from a Tertiary Care Center, North India. Indian J. Pathol. Microbiol. 2013, 56, 144-147. [CrossRef]

186. Salari, S.; Sadat Seddighi, N.; Ghasemi Nejad Almani, P. Evaluation of Biofilm Formation Ability in Different Candida Strains and Anti-Biofilm Effects of $\mathrm{Fe}_{3} \mathrm{O}_{4}$-NPs Compared with Fluconazole: An in vitro Study. J. Mycol. Med. 2018, 28, 23-28. [CrossRef]

187. Tellapragada, C.; Eshwara, V.K.; Johar, R.; Shaw, T.; Malik, N.; Bhat, P.V.; Kamath, A.; Mukhopadhyay, C. Antifungal Susceptibility Patterns, in vitro Production of Virulence Factors, and Evaluation of Diagnostic Modalities for the Speciation of Pathogenic Candida from Blood Stream Infections and Vulvovaginal Candidiasis. J. Pathog. 2014, 2014, 142864. [CrossRef]

188. Furlaneto, M.C.; Góes, H.P.; Perini, H.F.; Dos Santos, R.C.; Furlaneto-Maia, L. How Much Do We Know about Hemolytic Capability of Pathogenic Candida Species? Folia Microbiol. 2018, 63, 405-412. [CrossRef]

189. Luo, G.; Samaranayake, L.P.; Cheung, B.P.K.; Tang, G. Reverse transcriptase polymerase chain reaction (RT-PCR) detection of HLP gene expression in Candida glabrata and its possible role in in vitro haemolysin production. Apmis 2004, 112, 283-290. [CrossRef]

190. Nevitt, T.; Thiele, D.J. Host Iron Withholding Demands Siderophore Utilization for Candida glabrata to Survive Macrophage Killing. PLoS Pathog. 2011, 7, e1001322. [CrossRef] [PubMed]

191. Araújo, D.; Henriques, M.; Silva, S. Portrait of Candida Species Biofilm Regulatory Network Genes. Trends Microbiol. 2017, 25, 62-75. [CrossRef]

192. Cavalheiro, M.; Teixeira, M.C. Candida Biofilms: Threats, Challenges, and Promising Strategies. Front. Med. 2018, 5, 28. [CrossRef]

193. Guo, X.; Zhang, R.; Li, Y.; Wang, Z.; Ishchuk, O.P.; Ahmad, K.M.; Wee, J.; Piskur, J.; Shapiro, J.A.; Gu, Z. Understand the Genomic Diversity and Evolution of Fungal Pathogen Candida glabrata by Genome-Wide Analysis of Genetic Variations. Methods 2020, 176, 82-90. [CrossRef]

194. Pannanusorn, S.; Fernandez, V.; Römling, U. Prevalence of Biofilm Formation in Clinical Isolates of Candida Species Causing Bloodstream Infection. Mycoses 2013, 56, 264-272. [CrossRef] [PubMed]

195. Kunyeit, L.; Kurrey, N.K.; Anu-Appaiah, K.A.; Rao, R.P. Probiotic Yeasts Inhibit Virulence of Non-albicans Candida Species. mBio 2019, 10, e02307-19. [CrossRef] 
196. Cataldi, V.; Di Campli, E.; Fazii, P.; Traini, T.; Cellini, L.; Di Giulio, M. Candida Species Isolated from Different Body Sites and Their Antifungal Susceptibility Pattern: Cross-Analysis of Candida albicans and Candida glabrata Biofilms. Med. Mycol. 2017, 55, 624-634. [CrossRef]

197. Pongrácz, J.; Benedek, K.; Juhász, E.; Iván, M.; Kristóf, K. In vitro Biofilm Production of Candida Bloodstream Isolates: Any Association with Clinical Characteristics? J. Med. Microbiol. 2016, 65, 272-277. [CrossRef] [PubMed]

198. Kraneveld, E.A.; de Soet, J.J.; Deng, D.M.; Dekker, H.L.; de Koster, C.G.; Klis, F.M.; Crielaard, W.; de Groot, P.W.J. Identification and Differential Gene Expression of Adhesin-like Wall Proteins in Candida glabrata Biofilms. Mycopathologia 2011, 172, 415-427. [CrossRef]

199. de Groot, P.W.J.; Kraneveld, E.A.; Yin, Q.Y.; Dekker, H.L.; Gross, U.; Crielaard, W.; de Koster, C.G.; Bader, O.; Klis, F.M.; Weig, M. The cell wall of the human pathogen Candida glabrata: Differential incorporation of novel adhesin-like wall proteins. Eukaryot. Cell 2008, 7, 1951-1964. [CrossRef]

200. Leiva-Peláez, O.; Gutiérrez-Escobedo, G.; López-Fuentes, E.; Cruz-Mora, J.; De Las Peñas, A.; Castaño, I. Molecular Characterization of the Silencing Complex SIR in Candida glabrata Hyperadherent Clinical Isolates. Fungal Genet. Biol. 2018, 118, 21-31. [CrossRef] [PubMed]

201. Santos, R.; Costa, C.; Mil-Homens, D.; Romão, D.; de Carvalho, C.C.C.R.; Pais, P.; Mira, N.P.; Fialho, A.M.; Teixeira, M.C. The Multidrug Resistance Transporters CgTpo1_1 and CgTpo1_2 Play a Role in Virulence and Biofilm Formation in the Human Pathogen Candida glabrata. Cell. Microbiol. 2017, 19, e12686. [CrossRef] [PubMed]

202. Santos, R.; Cavalheiro, M.; Costa, C.; Takahashi-Nakaguchi, A.; Okamoto, M.; Chibana, H.; Teixeira, M.C. Screening the Drug:H+ Antiporter Family for a Role in Biofilm Formation in Candida glabrata. Front. Cell. Infect. Microbiol. 2020, 10, 29. [CrossRef] [PubMed]

203. Choudhary, D.K.; Bhakt, P.; Kaur, R. Essential Role for the Phosphatidylinositol 3,5-Bisphosphate Synthesis Complex in Caspofungin Tolerance and Virulence in Candida glabrata. Antimicrob. Agents Chemother. 2019, 63, e00886-19. [CrossRef] [PubMed]

204. Gonçalves, B.; Fernandes, L.; Henriques, M.; Silva, S. Environmental PH Modulates Biofilm Formation and Matrix Composition in Candida albicans and Candida glabrata. Biofouling 2020, 36, 621-630. [CrossRef] [PubMed]

205. Gonçalves, B.; Azevedo, N.M.; Henriques, M.; Silva, S. Hormones Modulate Candida Vaginal Isolates Biofilm Formation and Decrease Their Susceptibility to Azoles and Hydrogen Peroxide. Med. Mycol. 2020, 58, 341-350. [CrossRef]

206. Silva, S.; Negri, M.; Henriques, M.; Oliveira, R.; Williams, D.; Azeredo, J. Silicone Colonization by Non-Candida albicans Candida Species in the Presence of Urine. J. Med. Microbiol. 2010, 59, 747-754. [CrossRef] [PubMed] 